\title{
Cognitieve Therapie bij Depressieve Stoornissen
}

Citation for published version (APA):

Bockting, C. L. H., \& Lemmens, L. H. J. M. (2019). Cognitieve Therapie bij Depressieve Stoornissen. In S. M. Bögels, \& P. van Oppen (Eds.), Cognitieve Therapie: Theorie en Praktijk (3 ed., pp. 69-101). Bohn Stafleu van Loghum. https://doi.org/10.1007/978-90-368-2021-9_4

Document status and date:

Published: 01/01/2019

DOI:

10.1007/978-90-368-2021-9_4

Document Version:

Publisher's PDF, also known as Version of record

Document license:

Taverne

\section{Please check the document version of this publication:}

- A submitted manuscript is the version of the article upon submission and before peer-review. There can be important differences between the submitted version and the official published version of record.

People interested in the research are advised to contact the author for the final version of the publication, or visit the DOI to the publisher's website.

- The final author version and the galley proof are versions of the publication after peer review.

- The final published version features the final layout of the paper including the volume, issue and page numbers.

Link to publication

\footnotetext{
General rights rights.

- You may freely distribute the URL identifying the publication in the public portal. please follow below link for the End User Agreement:

www.umlib.nl/taverne-license

Take down policy

If you believe that this document breaches copyright please contact us at:

repository@maastrichtuniversity.nl

providing details and we will investigate your claim.
}

Copyright and moral rights for the publications made accessible in the public portal are retained by the authors and/or other copyright owners and it is a condition of accessing publications that users recognise and abide by the legal requirements associated with these

- Users may download and print one copy of any publication from the public portal for the purpose of private study or research.

- You may not further distribute the material or use it for any profit-making activity or commercial gain

If the publication is distributed under the terms of Article $25 \mathrm{fa}$ of the Dutch Copyright Act, indicated by the "Taverne" license above, 


\section{Cognitieve therapie bij depressieve stoornissen}

Claudi L.H. Bockting en Lotte H.J.M. Lemmens

\section{Samenvatting}

In dit hoofdstuk wordt de cognitieve therapie bij depressieve stoornissen besproken. Cognitieve therapie (CT) voor depressie is onlosmakelijk verbonden met gedragsmatige interventies, daarom zullen deze ook aan bod komen. Allereerst schetsen we kort het klinisch beeld van depressie en worden prevalentiecijfers gepresenteerd. Vervolgens wordt het theoretisch model dat ten grondslag ligt aan de behandeling besproken. We richten ons hierbij specifiek op het cognitieve model van depressie, zoals beschreven door Beck. Niet alleen omdat dit model het meest onderzocht is, maar ook omdat de interventiemethoden die uit dit model zijn voortgevloeid het meest invloedrijk zijn gebleken voor de klinische praktijk. Daarna wordt de behandeling geïllustreerd. We bespreken de kerninterventies en kenmerkende thema's van CT voor depressie en gaan in op specifieke aandachtspunten en mogelijke valkuilen. Het hoofdstuk wordt afgesloten met een overzicht van therapie-effectstudies.

\subsection{Inleiding - 71}

4.2 Depressieve stoornissen - 71

4.3 Cognitieve modellen van depressie - 71

4.4 Behandeling -75

4.4.1 Rationale - 77

4.4.2 Registratie en opbouw - 77

4.4.3 Het gedragsmatig model -81

4.4.4 Thema's -84

De auteurs danken Niek B. Berndes voor zijn bijdrage aan een eerdere versie van dit hoofdstuk. 
4.5 Valkuilen - 93

4.6 Therapie-effectstudies - 95

4.6.1 Cognitieve (gedrags)therapie versus antidepressiva - 96

4.6.2 Cognitieve (gedrags)therapie versus andere vormen van psychotherapie - 96

Bijlage 4.1 Dagboekformulier 1: activiteiten - 98

Literatuur -98 


\subsection{Inleiding}

In dit hoofdstuk wordt de cognitieve therapie (CT) bij depressieve stoornissen besproken. Omdat CT voor depressie onlosmakelijk verbonden is met gedragsmatige interventies, zoals gedragsactivatie, komen ook deze aan bod. Allereerst schetsen we kort het klinisch beeld van depressie en worden prevalentiecijfers gepresenteerd. Vervolgens wordt het theoretisch model dat ten grondslag ligt aan de behandeling besproken. We richten ons hierbij specifiek op het cognitieve model van depressie zoals beschreven door Beck. Niet alleen omdat dit model het meest onderzocht is, maar ook omdat de interventiemethoden die uit dit model zijn voortgevloeid het meest invloedrijk zijn gebleken voor de klinische praktijk. Daarna wordt de behandeling geillustreerd. We bespreken de kerninterventies en kenmerkende thema's van CT bij depressie, en gaan in op specifieke aandachtspunten en mogelijke valkuilen. Het hoofdstuk wordt afgesloten met een overzicht van therapie-effectstudies.

\subsection{Depressieve stoornissen}

De DSM-5 (APA 2013) spreekt van een depressieve stoornis wanneer er gedurende een periode van minimaal twee weken sprake is van somberheid ofwel interesseverlies met daarbij ten minste vijf aanvullende symptomen. Wanneer (een deel van) de klachten langer dan twee jaar aanhouden, spreekt men van een persisterende depressieve stoornis; voorheen - afhankelijk van de ernst en het aantal klachten - verder onderverdeeld in dysthymie en chronische depressie.

Epidemiologisch onderzoek - nog veelal gebaseerd op DSM-IV-classificaties (APA 2000) - laat zien dat depressieve stoornissen samen met de angststoornissen behoren tot de meest prevalente psychische stoornissen. De meest recente cijfers uit Nederlands onderzoek (NEMESIS-2) laten zien dat circa één op de vier vrouwen en één op de zeven mannen ooit in hun leven een depressie krijgt (depressie in engere zin of dysthymie; de Graaf et al. 2012). De jaarprevalentie voor de depressieve stoornis in Nederland wordt geschat op 5,2 \%. Dit komt overeen met ongeveer 546.500 mensen. Dysthymie komt jaarlijks voor bij ongeveer $1 \%$ van de Nederlandse bevolking (90.400 mensen; de Graaf et al. 2010).

Cijfers voor een chronisch beloop van depressie variëren van 20-30\% in de algemene bevolking (de Graaf et al. 2012; Satyanarayana et al. 2009), tot bijna $50 \%$ in de specialistische GGZ (Arnow en Constantino 2003). In de Nederlandse Studie voor Depressie en Angst (NESDA), waarin gegevens van patiënten uit de algemene bevolking, de generalistische basis-GGZ en de specialistische GGZ werden meegenomen, werd gevonden dat $33 \%$ van de depressies een chronisch beloop heeft (Wiersma et al. 2009). Ook bij succesvolle behandeling is de kans op terugval groot. Het is dus belangrijk dat depressiebehandelingen zich niet alleen richten op beter worden, maar ook op beter blijven.

\subsection{Cognitieve modellen van depressie}

In deze paragraaf bespreken we het cognitieve model van depressie, zoals beschreven door Beck (Beck 1967, 1987; Beck et al. 1979). Hoewel ook door anderen cognitieve modellen zijn beschreven (zoals het 'learned helplessness'-model van Abramson et al. (1978), of de rationeel-emotieve therapie (RET) van Ellis (1962)), is het model van Beck het meest onderzocht. Bovendien zijn de interventiemethoden die zijn voortgevloeid uit dit model het meest invloedrijk gebleken voor de klinische praktijk. 
Beck onderscheidt drie samenhangende cognitieve processen als kenmerkend voor de depressieve persoon:

- de cognitieve triade;

- fouten in de informatieverwerking;

- negatieve zelfschema's.

Met de cognitieve triade wordt bedoeld dat depressieve personen een negatieve kijk hebben op:

- zichzelf ('Ik kan niets');

- de toekomst ('Bij mij zal alles fout gaan');

- de wereld ('Mensen mogen me niet').

Kenmerkend voor de depressieve persoon is dat deze geneigd is situaties negatief te interpreteren, terwijl ook andere (meer positieve of neutrale) interpretaties mogelijk zouden kunnen zijn. Deze negatieve interpretaties leiden tot een negatieve stemming en een verlaagd activiteitenniveau. Meer specifiek veronderstelt Beck dat de informatieverwerking bij depressie gekenmerkt wordt door een aantal karakteristieke systematische denkfouten, zoals:

- overgeneralisatie (een betrekkelijk onbeduidend voorval leidt tot verregaande conclusies);

- personalisatie (iemand neemt ten onrechte de verantwoordelijkheid voor een negatieve gebeurtenis op zich);

- dichotoom denken (alles of niets denken; zwart-witdenken);

- willekeurige gevolgtrekking (neiging om negatieve conclusies te trekken zonder bewijs);

- selectieve abstractie (een klein negatief detail maakt dat de gehele gebeurtenis negatief geïnterpreteerd wordt);

- vergroting van (het belang van) negatieve gebeurtenissen, terwijl (het belang van) positieve gebeurtenissen verkleind worden.

Onderzoek heeft aangetoond dat de waarneming van depressieve patiënten inderdaad in negatieve zin vertekend is (Carson et al. 2010). Er zijn overigens ook aanwijzingen dat mensen met depressieve klachten de werkelijkheid juist accurater zouden waarnemen dan mensen zonder klachten (depressief-realisme; Alloy en Abramson 1988). Een meer recente meta-analyse liet echter zien dat dit fenomeen minder sterk en universeel aanwezig is dan men in eerste instantie dacht (Moore en Fresco 2012).

Het model van Beck veronderstelt dat ervaringen van mensen leiden tot het vormen van attitudes en schema's (-fig. 4.1). Schema's zijn opvattingen die mensen hebben over zichzelf, de wereld en de toekomst. Deze schema's, ook wel attitudes en kernopvattingen genoemd, worden gebruikt om waarnemingen te organiseren en om gedrag te regelen en te evalueren. Van belang is om op te merken dat er een onderscheid wordt gemaakt tussen schema's (kernovertuigingen) en attitudes. Attitudes nemen vaak de vorm aan van conditionele beweringen, zoals de volgende disfunctionele attitudes: 'Als mensen erachter komen wie ik werkelijk ben, zullen ze me in de steek laten', of 'Als ik niet perfect ben, ben ik waardeloos'. Schema's zouden ten grondslag liggen aan deze attitudes. Voorbeelden van schema's zijn: 'Ik ben geboren voor het ongeluk', en 'Ik ben waardeloos'. Het is echter de vraag of dit theoretisch onderscheid daadwerkelijk noodzakelijk is om te komen tot een effectieve behandeling.

De vaardigheid om betekenis aan een ervaring toe te kennen en consequenties te kunnen voorspellen, is noodzakelijk voor het dagelijks functioneren. Sommige schema's zijn echter zeer rigide, te extreem in veel gevallen, waardoor ze minder goed werken. Deze beperkende 
(vroege) ervaringen

vorming van beperkende attitudes/schema's

kritische gebeurtenissen

beperkende attitudes/schema's worden geactiveerd

negatieve automatische gedachten

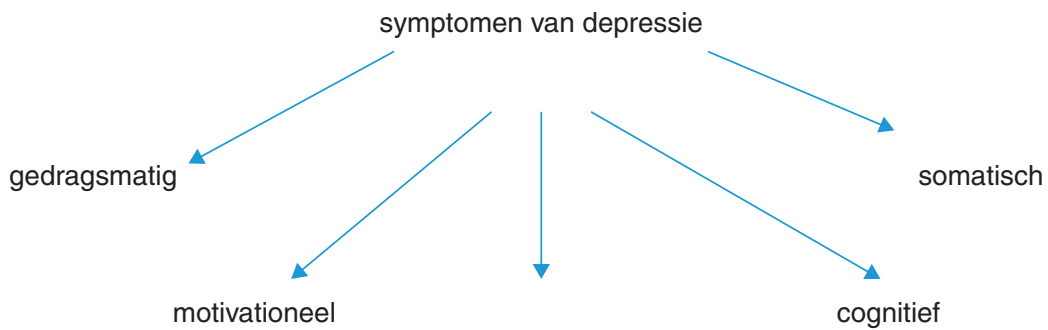

affectief

- Figuur 4.1 Beck's cognitieve model van depressie

schema's zijn gevormd op grond van allerhande gebeurtenissen gedurende het gehele leven, al geeft Beck aan dat gebeurtenissen in de kindertijd een grote impact kunnen hebben gehad op de vorming van schema's. Sommige beperkende schema's hebben betrekking op wat mensen nodig hebben om gelukkig te zijn (zoals 'Ik kan alleen gelukkig zijn als iedereen van mij houdt') en wat men moet doen om zichzelf waardevol te vinden (zoals 'Ik moet alles perfect doen, anders ben ik waardeloos').

Beperkende schema's en attitudes kunnen lange tijd sluimerend aanwezig zijn zonder dat ze problemen opleveren. Bepaalde situaties kunnen er echter voor zorgen dat een schema ge(her)activeerd wordt. Volgens het oorspronkelijke cognitieve model gebeurt dit alleen indien er iets gebeurt dat qua inhoud overeenkomt met een specifiek schema, zoals de verhuizing 
negatieve gedachten

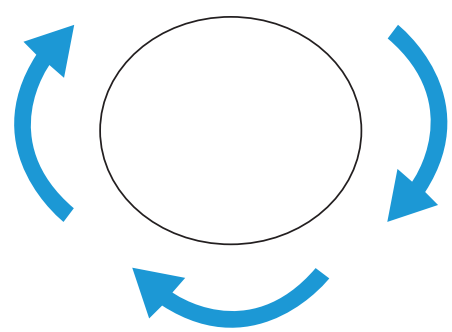

somberheid

geloofwaardigheid

- Figuur 4.2 De vicieuze depressieve cirkel

van een vriendin bij iemand met het schema 'Iedereen laat mij in de steek'. Recentere cognitieve modellen stellen echter dat reactivering van schema's ook kan plaatsvinden door kleine hoeveelheden stress en zelfs al door een licht sombere stemming (Segal et al. 2006). Er is gemengd bewijs voor de activerende rol van stemming op schema's (o.a. Elgersma et al. 2015; van Rijsbergen et al. 2013, 2015).

$\mathrm{Na}$ activering van het schema zou een cascade aan negatieve gedachten worden opgeroepen, die op hun beurt resulteren in gevoelens van somberheid en andere depressieve klachten. Naarmate de depressieve klachten toenemen, komen de negatieve gedachten steeds frequenter voor en worden ze intenser en geloofwaardiger. Dit versterkt de somberheid en zo is de vicieuze cirkel gevormd; hoe depressiever een persoon wordt, hoe meer negatieve gedachten, hoe meer de persoon dit gaat geloven en des te depressiever hij wordt (•fig. 4.2).

\section{Marijke}

Marijke is een jonge vrouw met een matig-ernstige depressie. Sinds haar afstuderen, nu bijna een jaar geleden, werkt ze als administratief medewerkster bij een groothandel. Drie maanden geleden gaf haar baas aan dat hij haar contract niet kon verlengen in verband met de financiële situatie van het bedrijf. Vervolgens werd Marijke depressief. Tijdens de behandeling kwam naar voren dat Marijke niet begreep waarom dit haar zo somber maakte. Het was toch maar werk? Na gebruik van de neerwaartse-pijltechniek bleek dat deze gebeurtenis haar schema dat ze in wezen waardeloos is, reactiveerde. Marijke vertelde dat zij zich uit haar jeugd diverse momenten kon herinneren dat ze niet aan de verwachtingen van haar ouders kon voldoen. Bijvoorbeeld zoals toen ze haar schooladvies kreeg op de basisschool. Haar ouders hadden gehoopt op VWO-advies en hadden veel geld betaald voor extra cito-trainingen. Toen ze niet, net als haar broer en zus, naar het gymnasium kon maar naar het VMBO moest, werden haar ouders erg boos op haar. Marijke kan zich herinneren dat vader zei dat ze nergens goed in was. Haar broer en zus zijn allebei zeer succesvol, wat haar keer op keer bevestigt in het idee dat zij waardeloos is. Een voorbeeld hiervan is weergegeven in -fig. 4.3. 
(vroege) ervaringen

veeleisende ouders

succesvolle broer en zus

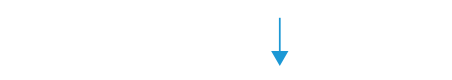

vorming van beperkende attitudes/schema's

Ik ben waardeloos

kritische gebeurtenissen

contract niet verlengd op het werk

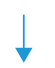

beperkende attitude wordt geactiveerd

Ik ben waardeloos

negatieve automatische gedachten

Ik ben niet leuk

Ik kan niets

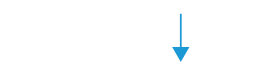

symptomen van depressie

somber

interesseverlies

concentratieproblemen

inslaapproblemen

schuldgevoelens

gewichtsverlies

- Figuur 4.3 Beck's cognitieve model van depressie geillustreerd (casus Marijke)

\subsection{Behandeling}

In deze paragraaf bespreken we de kerninterventies, kenmerkende thema's en een aantal specifieke aandachtspunten binnen de CT voor depressie. Tevens zullen gedragsinterventies aan bod komen. Voor een uitgebreide sessiegewijze beschrijving van cognitieve (gedrags)therapie $(\mathrm{C}(\mathrm{G}) \mathrm{T})$ bij depressie wordt verwezen naar onder anderen Boelens en Bloedjes (2012) en Bockting, van Rijsbergen en Huibers (2017). 
CT voor depressie beslaat gemiddeld twaalf tot zestien sessies. Dit is echter niet voor iedereen nodig of voldoende. Een studie door Bockting en Baas (2010) liet zien dat voor patienten die behandeld worden in de generalistische basis-GGZ, een behandeling van acht sessies al effectief kan zijn (al zijn de effecten niet vergeleken met een behandeling CT met meer sessies). Bij complexere problematiek - bijvoorbeeld wanneer er sprake is van chroniciteit of comorbiditeit - zijn mogelijk meer dan zestien sessies nodig (Spijker et al. 2013).

De belangrijkste interventies die voortvloeien uit het cognitieve model zijn:

- identificatie en registratie van negatieve automatische gedachten;

- kritisch onderzoeken van automatische gedachten en formuleren van meer helpende alternatieven;

- identificatie van onderliggende schema's en attitudes;

- kritisch onderzoeken van schema’s en attitudes en formuleren van meer helpende alternatieven.

Het proces van onderzoeken van gedachten werd lange tijd uitdagen genoemd. Inmiddels spreekt men ook wel over het evalueren of exploreren van gedachten. Dit zorgt voor een meer open manier van onderzoeken. Het is namelijk de bedoeling om te komen tot een eerlijk onderzoek waarin alle uitkomsten mogelijk zijn (dus ook een bevestiging van de negatieve gedachte). De term uitdagen suggereert mogelijk sterker dat de automatische gedachte per definitie al niet (helemaal) klopt, terwijl dit dus niet het geval hoeft te zijn.

Een veelgebruikte methode om negatieve automatische gedachten, schema's en attitudes te onderzoeken is de socratische dialoog. Hierin wordt de patiënt middels onderzoekende vragen geholpen om tot nieuwe inzichten te komen. Hierbij wordt gebruikgemaakt van de geleide ontdekking ('guided discovery'). De therapeut en patiënt zoeken samen naar alternatieve verklaringen, waarbij de therapeut het proces bewaakt en de patiënt de inhoud levert. Vragen die een patiënt leert te stellen zijn onder meer: Is de gedachte reëel? Klopt deze helemaal? Klopt deze op dit moment? Wat zijn de bewijzen voor en tegen? Gaat de gedachte helemaal op? Is dit altijd het geval? Weet ik voldoende of moet ik meer informatie zoeken? Zijn er alternatieve verklaringen mogelijk? Wat is het ergste dat er kan gebeuren? Maak ik een denkfout? Wat zou iemand anders doen?

Omdat depressie vaak gepaard gaat met concentratieproblemen, is deze wijze van bevragen soms erg moeilijk. In dat geval is een simpeler methode aan te raden, waarin het uitdagen aanvankelijk beperkt wordt tot het zoeken van bewijzen voor en bewijzen tegen de gedachte (Beck et al. 1979; Beck 2011). Op basis van de informatie die verzameld is in de socratische dialoog, wordt een weloverwogen conclusie getrokken over de gedachte. Indien nodig wordt er een alternatieve gedachte opgesteld die tegenover de disfunctionele automatische gedachte kan worden gezet.

Andere veelgebruikte cognitieve technieken om gedachten bij depressie te onderzoeken zijn de continuümtechniek en de neerwaartse-pijltechniek ( $\triangleright$ H.2 en 3). Bij deze laatstgenoemde wordt doorgevraagd naar de betekenis en de consequenties van een bepaalde negatieve opvatting. In de meest simpele vorm bestaat deze techniek uit twee vragen: 'Als wat je denkt daadwerkelijk waar is, wat betekent dat dan voor jou?' (om assumpties te identificeren) en 'Als wat je denkt daadwerkelijk waar is, wat zegt dit dan over jezelf en de toekomst' (om kerngedachten te identificeren; $>$ par. 3.3). Deze techniek is met name bruikbaar indien er sprake is van forse vermijding, hetgeen kenmerkend is voor veel mensen met een depressie (Bockting et al. 2006), of wanneer het uitdagen uitsluitend op rationeel niveau blijft hangen zonder de bijbehorende emoties. 
In CT voor depressie wordt daarnaast ook veel gebruikgemaakt van gedragsexperimenten. Deze worden niet alleen ingezet om bestaande negatieve automatische gedachten en leefregels te evalueren, maar ook om de houdbaarheid van nieuw gevormde alternatieve, meer helpende gedachten te toetsen.

\subsubsection{Rationale}

De rationale van de behandeling wordt bij voorkeur uitgelegd aan de hand van meerdere concrete voorbeelden uit het leven van de patiënt. Het is daarbij belangrijk om rekening te houden met het feit dat veel depressieve patiënten concentratieproblemen hebben. Mensen met een depressie zijn bovendien erg gevoelig voor falen. Probeer daarom in beginsel niet meer dan de basisprincipes van CT uit te leggen: namelijk dat mensen met depressie negatieve gedachten hebben en dat deze gedachten sterk van invloed zijn op het gevoel. Dit kan geillustreerd worden door specifieke situaties te bespreken waarin gedachten van de patiënt van invloed waren op de stemming. De bespreking van attitudes en schema's kan in een later stadium aan bod komen. Dan wordt, bij voorkeur opnieuw aan de hand van eigen voorbeelden, duidelijk gemaakt dat iemand zich in een vicieuze cirkel bevindt, waarin het lage activiteitenniveau geldt als bewijs voor negatieve (zelf)opvattingen en waarin die negatieve opvattingen op hun beurt weer leiden tot verdere ontmoediging om activiteiten te ontplooien.

Daarnaast is het belangrijk om uitgebreide informatie te geven over depressie (psychoeducatie). Depressieve patiënten hebben de neiging om de depressieve symptomen te zien als bewijs van persoonlijk falen en tekortschieten. Het is verstandig uitleg te geven over de apathie die depressie in veel gevallen met zich meebrengt. Veel depressieve mensen vertellen dat de intuitie aangeeft dat ze helemaal niets meer moeten doen of zelfs dat het slecht voor ze is om iets te ondernemen. Alleen al het aangaan van een behandeling is dus een grote stap, waarmee ze zich verzetten tegen wat het gevoel hen ingeeft. Echter, niets doen houdt depressie in stand of verergert deze zelfs.

Tot slot is het belangrijk dat de patiënt door de rationale van de behandeling hoop op verbetering geboden wordt. De meeste depressieve patiënten komen binnen met de verwachting: 'Bij mij zal dit niet werken.' Hierbij kan het zinvol zijn de kennis over de evidentie van CT met de patiënt te delen, zoals door te bespreken dat we weten dat CT werkt bij veel mensen met vergelijkbare klachten. Het is doorgaans zeer gebruikelijk dat een depressieve patiënt de behandeling start zonder dat hij volledig overtuigd is van de mogelijkheid dat deze therapie hem zal helpen.

\subsubsection{Registratie en opbouw}

Na de uitleg van de rationale - zoals gebruikelijk is bij cognitieve (gedrags)therapie $(C(G) T)$ wordt met behulp van registratieformulieren goed in kaart gebracht hoe het nu gaat ( bijlage 4.1). Bij depressieve patiënten met een zeer laag activiteitenniveau wordt doorgaans begonnen met registratie van dagelijkse activiteiten om een goed beeld te krijgen van het activiteitenniveau van de patiënt (-fig.4.4). Vervolgens kan gedragsmatige activatie gestart worden. 


\begin{tabular}{|c|c|c|c|c|}
\hline \multicolumn{5}{|c|}{$\begin{array}{l}\text { DAGBOEKFORMULIER } \\
\text { naam: } \\
\text { datum: }\end{array}$} \\
\hline $\begin{array}{l}\text { tijd } \\
\text { van/tot }\end{array}$ & activiteit & $\begin{array}{l}\text { gemiddelde } \\
\text { stemming (1) }\end{array}$ & $\begin{array}{l}\text { noodzakelijke } \\
\text { activiteit (2) }\end{array}$ & $\begin{array}{l}\text { plezierige } \\
\text { activiteit (2) }\end{array}$ \\
\hline \multicolumn{5}{|l|}{ (ochtend) } \\
\hline $7.00-8.00$ & $\begin{array}{l}\text { opstaan, ontbijt klaar- } \\
\text { maken, kinderen naar } \\
\text { school helpen }\end{array}$ & 4 & + & \\
\hline $8.00-9.30$ & $\begin{array}{l}\text { boel afruimen, opruimen, } \\
\text { krant lezen }\end{array}$ & 5 & + & - \\
\hline $9.30-12.00$ & $\begin{array}{l}\text { op de bank gezeten, niets } \\
\text { bijzonders gedaan }\end{array}$ & 3 & - & - \\
\hline \multicolumn{5}{|l|}{ (middag) } \\
\hline $12.00-13.30$ & middageten, boel afruimen & 5 & + & \\
\hline $13.30-14.30$ & $\begin{array}{l}\text { bovenboel gedaan, was } \\
\text { gedaan }\end{array}$ & 5 & + & \\
\hline $14.30-17.00$ & $\begin{array}{l}\text { zitten, niets gedaan, even } \\
\text { ingedommeld }\end{array}$ & 3 & - & \\
\hline $17.00-18.00$ & $\begin{array}{l}\text { koffiedrinken met Jan, } \\
\text { koken }\end{array}$ & 5 & $+/-$ & + \\
\hline \multicolumn{5}{|l|}{ (avond) } \\
\hline $18.00-19.00$ & eten, boel afruimen & 5 & + & \\
\hline $19.00-20.00$ & $\begin{array}{l}\text { spelletje met de kinderen } \\
\text { gedaan, kinderen naar bed } \\
\text { gebracht }\end{array}$ & 5 & & + \\
\hline $20.00-21.30$ & tv gekeken & 6 & + & $?$ \\
\hline 21.30 & naar bed & & & \\
\hline
\end{tabular}

(1) $0=$ zeer somber, $10=$ zeer vrolijk.

(2) $+=$ succesvol, $-=$ niet succesvol, ? = noch het een, noch het ander.

- Figuur 4.4 Ingevuld dagboekformulier (activiteiten) 
Als volgende stap wordt het gedachtedagboek geïntroduceerd. Dit heeft als doel om het verband tussen situaties, gedachten en gevoel meer systematisch in kaart te brengen. Een dialoog in de beginfase van de behandeling zou kunnen verlopen, zoals hierna beschreven:

I) Th. Ik wil het vandaag met je hebben over het verband tussen gebeurtenissen, gedachten en gevoelens. Kun je je een moment herinneren de afgelopen week dat het niet lekker ging op je werk?

P. Nou en of! Woensdagavond belde de directrice van de basisschool waar ik werk me op. Ze vroeg me of ik donderdag kon vervangen voor een zieke collega. Donderdag is mijn vrije dag, maar omdat ik weet hoe moeilijk het is om last-minute een vervanger te vinden, heb ik toegezegd. Toen de directrice donderdag in de pauze de lerarenkamer binnenkwam, had ik verwacht dat ze me even zou aanspreken om me te bedanken. Maar dat deed ze niet. Ook andere collega's zeiden er niets over. Het resultaat was dat ik de rest van de dag heel ongeduldig en snauwerig ben geweest tegen de kinderen.

Th. Hoe voelde je je op dat moment?

$P$. Ik voelde me gespannen en geïriteerd omdat niemand er niets over zei.

Th. En wat ging er allemaal door je heen?

P. Ik denk vooral het idee dat niemand waardeert wat ik doe.

Th. Goed. Dat is een mooi voorbeeld van wat we een automatische gedachte noemen. ledereen heeft ze. Het zijn gedachten die direct in je hoofd opkomen zonder dat je daarvoor iets hoeft te doen. Meestal komt zo'n gedachte zo snel bij je naar boven dat je er helemaal geen erg in hebt. Maar het effect op je emoties is er wel. Die emoties merk je wel op, maar de gedachte niet. Vaak zijn die automatische gedachten niet erg logisch. En gewoonlijk sta je niet stil om de geloofwaardigheid van deze gedachte te onderzoeken. Maar hier doen we dat juist wel.

P. Ik begrijp het.

Th. Goed, vertel eens, wat is het effect van de gedachte dat niemand je waardeert?

P. Nou het maakt me woedend. Ik voel me zo miskend en mijn stemming wordt er alleen maar slechter op!

Th. Stel je nu eens voor wat het effect zou zijn als je je manier van denken zou veranderen.

P. Je bedoelt: als ik de gedachte dat niemand me waardeert, niet zou hebben?

Th. Dat bedoel ik.

P. Ik denk dat ik me dan veel gelukkiger zou voelen in mijn werk. Dat weet ik wel zeker! En ik denk dat ik dan aardiger zou zijn voor de kinderen. Minder snauwerig en geduldiger!

Daarna introduceert de therapeut het dagboek voor het bijhouden van gedachten. Een voorbeeld laten we zien in - fig. 4.5.

Het is van belang pas tot uitdagen over te gaan wanneer de negatieve gedachten voldoende duidelijk zijn. Het helpt daarbij om de vraag te stellen: is met deze automatische gedachten voldoende begrijpelijk dat de patiënt zich zo voelde? Indien dit niet het geval is, zijn er mogelijk andere negatieve gedachten die een rol spelen?

In de eerste sessies wordt nog niet ingegaan op onderliggende schema's. Dat gebeurt in een latere fase. Veel depressieve patiënten zijn zich vaak niet bewust welke dieperliggende gedachten een rol spelen of hebben geen toegang tot de emoties die daar mogelijk aan gekoppeld zijn. Vaak is er dan sprake van vermijding van pijnlijke gedachten of gevoelens. De therapeut dient hier met name alert op te zijn als bij de registratie (of in het gesprek) relatief triviale gebeurtenissen leiden tot een ernstige daling van de stemming zonder dat dit 


\section{FORMULIER BIJHOUDEN VAN GEDACHTEN}

Datum en tijd: donderdag 1 november, 10:00 uur

Situatie: Ik word niet bedankt door directie en collega's.

Gevoel: irritatie, boosheid, spanning (sterkte van gevoel: 75)

Automatische gedachte: Men waardeert mij niet (geloofwaardigheid: 70).

\section{Gedrag:}

- Terugtrekken, collega's en directie vermijden.

- Ongeduldig en bozig naar de kinderen.

\section{Uitdagen/evaluatie:}

- Bewijzen voor de gedachte:

- Ze bedanken me niet als ik inspring.

- Ze besteden geen aandacht aan me.

- Bewijzen tegen de gedachte:

- Ze zijn misschien te druk met werk om de tijd te nemen om me te bedanken.

- Collega's springen ook vaak in en worden dan ook niet bedankt.

- Het is normaal om dit binnen het team voor elkaar te doen. Ik bedank ze zelf ook niet.

Rationele gedachte: Ik doe er wel toe.

Resultaat: Geloofwaardigheid van de gedachte 'Niemand waardeert me' is laag (35). Ik heb wel de indruk dat ik ertoe doe (geloofwaardigheid 70 ). Ik voel me minder boos, ontspannen.

\section{Nieuw gedrag:}

- Minder streng afrekenen naar anderen en uitgaan van mijn sterke kant.

- Collega's en directie niet meer vermijden en in de lerarenkamer meepraten.

- Figuur 4.5 Ingevuld gedachtenboek

afdoende verklaard kan worden door de gerapporteerde automatische gedachten van de patiënt. In die gevallen kan het helpend zijn om een andere evaluatietechniek te gebruiken zoals de neerwaartse-pijltechniek ( $\triangleright$ par. 3.3). Overigens kan ook het gebruik van vragenlijsten, zoals de Disfunctionele Attitude Schaal (DAS: Raes et al. 2005; Weissman en Beck 1978), hierbij zeer behulpzaam zijn. Naast informatie over negatieve automatische gedachten kunnen dagboekformulieren informatie geven over mogelijke onderliggende attitudes en schema's. 


\section{Femke}

Uit de dagboeken van Femke blijkt dat ze zeer aangeslagen was toen ze erachter kwam dat ze de verjaardag van haar vriendin was vergeten. De therapeut begrijpt deze heftige reactie niet goed en vermoedt dat er andere gedachten een rol spelen. Zij vraagt door met behulp van de neerwaartse-pijltechniek.

॥ P. Nou ja, dat vergeet je toch niet, een verjaardag!

Th. Als dat inderdaad zo is, wat is daar voor jou zo erg aan?

P. Het had niet mogen gebeuren.

Th. Ja, kun je uitleggen wat daar zo erg aan is?

P. Ik maak overal een puinhoop van. Ik doe alles fout. Ik heb weer gefaald.

Th. Wat betekent dat voor jou?

P. Dat ik iedereen teleurstel.

Th. En wat betekent dat voor je?

P. Dan vinden ze me niet meer aardig.

Th. En wat betekent het voor je als ze je niet meer aardig vinden? En wat is daar precies zo erg aan?

P. Dan doe ik er niet meer toe, dan ben ik niets meer waard.

\subsubsection{Het gedragsmatig model}

Omdat cognitieve interventies in de regel gecombineerd worden met gedragsmatige interventies bij de behandeling van een depressie, besteden we in dit hoofdstuk tevens aandacht aan het gedragsmatige model en gedragsmatige interventies. In het gedragsmatig model wordt een depressieve stoornis beschouwd als zijnde depressief gedrag. Depressief gedrag zou ontstaan (of in stand gehouden worden) door onvoldoende positieve of inadequate bekrachtigers, als reactie op gedrag van de persoon in kwestie.

Een gedragstherapeutisch model waaruit gedragsmatige interventies voortvloeien die regelmatig op effectiviteit zijn onderzocht, is het model van Lewinsohn et al. (1986). In dit model wordt tevens de invloed van sociale bekrachtigers meegenomen. Dit model voorspelt dat het (sociale) gedrag in frequentie zal afnemen bij een gebrek aan positieve sociale bekrachtigers of wanneer ze leiden tot negatieve of stressvolle gevolgen. Dit brengt met zich mee dat de patiënt zich slechter zal voelen, bijvoorbeeld somberder en wanhopiger waardoor het activiteitenniveau nog verder afneemt. In -fig. 4.6 is deze vicieuze cirkel weergegeven.

De belangrijkste gedragsmatige interventies die voortvloeien uit dit model zijn gericht op het uitbreiden van potentieel plezierige activiteiten. Voordat overgegaan kan worden op deze interventie is het noodzakelijk om in kaart te brengen wat iemand dagelijks onderneemt en hoe iemand zich daarbij voelt. De relatie tussen activiteiten en stemming wordt inzichtelijk gemaakt door registratie. Hiervoor worden dagboekformulieren gebruikt, waarin de patiënt gevraagd wordt het tijdstip, de activiteit zelf en de stemming te omschrijven. Daarnaast dient de patiënt aan te geven of het een noodzakelijke activiteit is (zoals afwassen of rekeningen betalen) of een plezierige activiteit (zie - fig. 4.4). Afhankelijk van het activiteitenniveau van de patiënt worden keuzes gemaakt omtrent de frequentie van registreren. 


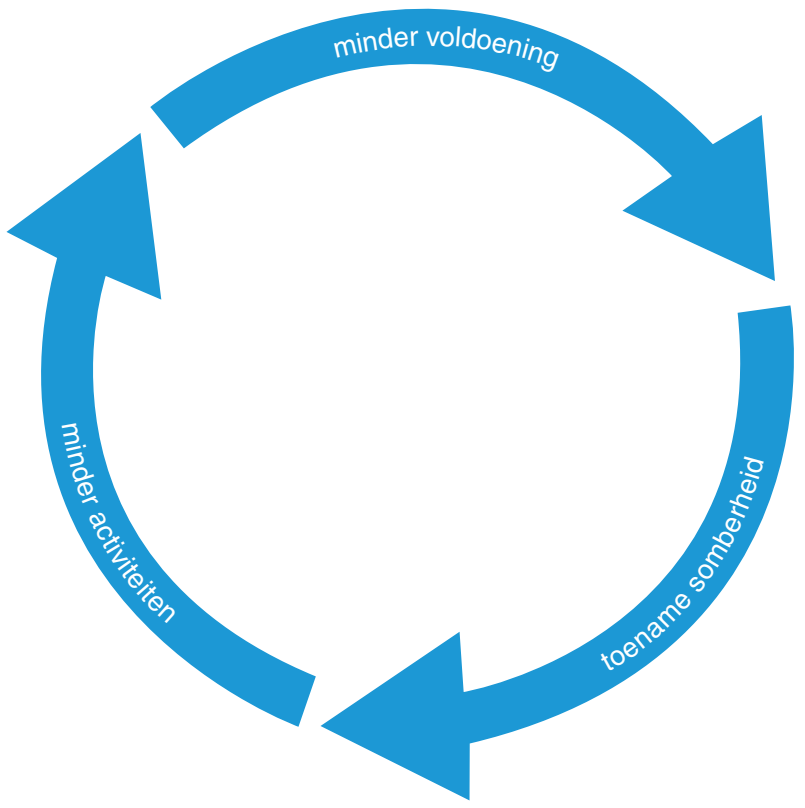

- Figuur 4.6 De vicieuze cirkel van activiteiten

De gedragsmatige rationale kan als volgt uitgelegd worden

'Dit onderdeel van de therapie bestaat uit het geleidelijk uitbreiden van plezierige en ontspannende activiteiten om de voldoening te doen toenemen. Het doel hiervan is vermindering van somberheid. Veel mensen met depressieve klachten merken dat ze steeds minder activiteiten ondernemen. Om een idee te krijgen van de dingen die u niet meer doet, en wat u nog wel doet, vragen wij u op papier bij te houden wat u doet. Ik zal met $u$ een voorbeeld uitwerken, zodat u weet wat de bedoeling is.'

\section{De vicieuze cirkel kan als volgt uitgelegd worden}

'Als u weinig meer onderneemt, krijgt u minder voldoening en dat kan ertoe leiden dat $u$ zich nog somberder gaat voelen. Wanneer u minder doet dan $\mathrm{u}$ van uzelf gewend bent, dan bestaan de dingen die u nog wel doet vaak uit minder plezierige activiteiten (de 'moetjes'). Wij gaan ervan uit dat wanneer $u$ weinig meer doet, dit de somberheid in stand houdt. $U$ zit als het ware in een vicieuze cirkel; hoe somberder $u$ bent, hoe minder $u$ onderneemt (en vooral de plezierige activiteiten vallen weg), hoe minder voldoening u krijgt en hoe somberder u vervolgens wordt. Zullen we eens samen kijken of dit op u van toepassing is?'

\section{Registratie van activiteiten}

Het is verstandig om de registratie in de sessie samen met de patiënt te starten, zodat mogelijke knelpunten ter plekke kunnen worden opgelost. Onze ervaring is dat de directe effecten van het registreren van het eigen activiteitenpatronen zowel positief als negatief kunnen zijn. 
Zo kan een depressieve patiënt ontdekken dat hij veel meer doet dan hij dacht. Maar we zien ook regelmatig dat patiënten somberder worden van het registreren omdat het bevestigt dat ze nog maar weinig doen en dat ze overwegend een zeer negatieve stemming hebben.

\section{Uitbreiden van plezierige activiteiten}

Op basis van de verzamelde informatie wordt gestart met het uitbreiden van plezierige activiteiten. Bij het zoeken naar plezierige activiteiten is van groot belang om na te gaan of deze daadwerkelijk potentieel plezierig zijn. Zo gaf een patiënte aan het prettig te vinden om te gaan wandelen met haar bejaarde buurvrouw. Maar nadat ze dit had gedaan, bleek dat het voor haar een negatieve activiteit was. Ze voelde zich hier schuldig over en dacht dat ze een slecht mens was. Ook in de tijd dat ze niet depressief was vond ze dit al geen prettige activiteit, maar ze vond altijd van zichzelf dat ze dit als buurvrouw zou moeten doen en daar ook plezier aan zou moeten beleven. Het betrof dus niet een plezierige activiteit, maar zoals de patiënte zelf zei een 'moet'-activiteit.

Gedragsmatige activatie is specifieker dan activeren in algemene zin. Het is belangrijk om rekening te houden met het feit dat het echt om uitbreiding van potentieel plezierige activiteiten gaat. Deze activiteiten moeten samen met de patiënt gezocht worden. Bij mensen met ernstige depressies zijn er regelmatig geen plezierige activiteiten meer. Het onderscheidend criterium voor de (anvankelijke) keuze van de activiteit is dan niet de mate van plezier, maar er kan ook gedacht worden aan activiteiten die de spanning verminderen of die de tijd wat sneller voorbij laten gaan. Ook kan er met de patiënt gezocht worden naar activiteiten die voor het ontstaan van de depressie plezierig waren.

Het soort activiteit moet natuurlijk afgestemd worden op het activiteitenniveau en de ernst van de depressie. Bij patiënten met een ernstige depressie kan gedacht worden aan kleine stappen, zoals even in de zon zitten, mooie muziek opzetten, een bad nemen, een aantal keer per week een wandeling maken enzovoort. Doorgaans heeft een depressieve patiënt voortdurend de indruk te falen. Om dit te doorbreken en de hoop en het vertrouwen in de therapie en therapeut te vergroten is het belangrijk dat de kans op slagen zo groot mogelijk is. Hierbij speelt de therapeut een belangrijke rol.

Het is bij gedragsmatige activatie daarnaast van belang dat er 'stemmingsonafhankelijk gepland' wordt. Dit betekent dat de patiënt van tevoren moet inplannen wanneer de activiteit wordt ondernomen, ongeacht hoe hij of zij zich op dat moment voelt. De activiteit moet daarom ook haalbaar zijn op de meest slechte momenten. Indien de patiënt juist nog veel onderneemt, zou in overleg met de patiënt het aantal 'moet'-activiteiten allereerst (tijdelijk) teruggebracht moeten worden. Vervolgens wordt het aantal potentieel plezierige activiteiten stap voor stap uitgebreid in nauw overleg met de patiënt.

De Pleasant Event Schedule (PES; Bouman en Luteijn 1986; MacPhillamy en Lewinsohn 1982 ) is een vragenlijst met tal van voorbeelden van plezierige activiteiten waarin de frequentie en de beleving kan worden ingevuld en vorderingen kunnen worden bijgehouden. Deze kan gebruikt worden om voorbeelden te vinden van plezierige activiteiten, maar ook om gedurende de behandeling te zoeken naar andersoortige plezierige activiteiten (bijvoorbeeld niet uitsluitend het aantal wandelingen uitbreiden, maar ook andersoortige activiteiten, zoals sociale activiteiten, oppakken).

Hoewel gedragsinterventies hier apart worden besproken, worden ze in de praktijk meestal gecombineerd aangeboden met cognitieve technieken. In de regel ligt de nadruk in de eerste sessies sterk op gedragsmatige interventies, waarna na enkele sessies de cognitieve 
interventies meer ruimte krijgen. Onderzoek heeft echter aangetoond dat de interventies niet noodzakelijkerwijs gecombineerd hoeven te worden om een effectieve behandeling voor depressie kunnen bieden ( $\triangleright$ par. 4.6).

\subsubsection{Thema's}

Het veranderen van de negatieve automatische gedachten is in veel gevallen niet voldoende ('Ik wéét wel dat ik er anders tegenaan moet kijken, maar het voelt niet anders'). $\mathrm{Na}$ een aantal sessies wordt de aandacht daarom gericht op het verduidelijken en bewerken van de onderliggende attitudes of schema's die centraal staan in de moeilijkheden van de patiënt.

Het opsporen van deze schema's vindt hoofdzakelijk plaats door stil te staan bij de centrale thema's die in de dagboeken en in de therapiesessies aan de orde zijn geweest. De volgende thema's komen bij depressieve patiënten vaak voor

- inactiviteit;

- negatieve zelfopvattingen en hoge eisen stellen aan zichzelf;

- verantwoordelijkheid en schuld;

- verlies.

\section{Inactiviteit}

Inactiviteit en apathie kunnen bij patiënten met een ernstige depressie een grote belemmering vormen voor het doen van huiswerk voor de cognitieve therapie, omdat zich in het dagelijkse leven van deze patiënten nog nauwelijks gebeurtenissen voor de CT voordoen. In de eerste fase van de behandeling kan het geven van registratieopdrachten dan zelfs al te veel gevraagd zijn. Dit is op te lossen door de registraties aanvankelijk met de patiënt in de sessie zelf te doen. Daarnaast helpt het soms om patiënten te vragen de gedachten en gevoelens in te spreken op hun smartphone in plaats van ze op te schrijven. Ook kan gedacht worden aan een zeer laagfrequente opdracht (één keer per week).

In de regel wordt bij deze mensen na de uitleg van de rationale begonnen met registratie van dagelijkse activiteiten om een goed beeld te krijgen van het activiteitenniveau van de patiënt. Binnen deze groep is de apathie en het vermijdingsgedrag echter vaak zo groot, dat het de voorkeur verdient om de behandeling in eerste instantie te richten op verhoging van het activiteitenniveau (met name potentieel plezierig gedrag). Hierbij dient het activiteitendagboek als uitgangspunt. Uitvoerige bespreking van de geregistreerde activiteiten levert veel informatie op over de negatieve gedachten die bij de patiënt een rol spelen. Ideeën van de patiënten over hun activiteitenniveau of stemmingsniveau kunnen dan direct getoetst worden.

\section{Gerard}

Gerard meldde in het eerste gesprek dat hij de hele dag op de bank lag en dat hij de hele dag altijd somber was ('Wat ik ook doe, ik voel me de hele dag ellendig'). Inspectie van de dagboeken tijdens de volgende sessie leverde echter het 'bewijs' op dat deze gedachten van Gerard niet overeenstemmen met de geregistreerde werkelijkheid. Gerard ligt per dag tussen de anderhalf en vier uur op de bank, en in het weekend helemaal niet. Zijn stemming fluctueert over de dag, wat samen lijkt te hangen met activiteiten die hij met zijn partner of kinderen onderneemt; dergelijke activiteiten leiden tot een stemmingsverbetering. 
De belangrijkste negatieve opvattingen die aan de inactiviteit en het vermijdingsgedrag ten grondslag liggen, worden gevonden door patiënten te vragen waarom zij bepaalde activiteiten niet meer ondernemen of door hen voor te stellen bepaalde activiteiten weer te gaan ondernemen.

\section{Gerard - vervolg}

Uit de redenen die Gerard aangeeft voor zijn inactiviteit komt een aantal negatieve automatische gedachten naar voren: 'Dat lukt me toch niet', 'Ik ben er te moe voor', 'Ik zou me daarna alleen nog maar beroerder voelen' en 'lk ben toch maar een last voor andere mensen'.

Dergelijke gedachten worden eerst op socratische wijze geëvalueerd door de geloofwaardigheid ervan te onderzoeken (bewijzen voor en tegen) en door het effect ervan op de stemming en het gedrag te bespreken. Op deze manier kon enige afstand kon nemen ten opzichte van zijn ideeën en nam hij zich voor de volgende week enige activiteiten te ontplooien (schaken, met zijn vrouw naar de film).

Niet iedere patiënt kan echter uitsluitend door middel van een socratische dialoog gemotiveerd worden het activiteitenniveau te verhogen. In dergelijke gevallen verdient het aanbeveling de gedragsmatige interventies meer ruimte te geven, bijvoorbeeld door een gedragsexperiment op te zetten.

\section{Josefien}

Josefien neemt het zichzelf kwalijk dat ze er niet meer toe komt om het huishouden naar behoren te doen. Ze eet kant-en-klaarmaaltijden of bestelt een pizza. Thuis is het een rommel geworden en haar huis moet nodig weer eens worden gepoetst. Josefien vertelt dat ze de energie niet heeft en dat ze zich alleen maar nog beroerder zou voelen als ze iets zou doen. Voorafgaande aan en als motivatie voor het verhogen van het activiteitenniveau stelt de therapeut voor een gedragsexperiment te doen. Er wordt afgesproken dat ze de komende zaterdag gedurende een half uur de huiskamer gaat stofzuigen om de gedachte te toetsen dat ze zich alleen maar nog beroerder zou voelen. De stemming wordt vooraf en achteraf geregistreerd.

Essentieel bij het opzetten van gedragsexperimenten is om patiënten zodanig te motiveren dat zij het experiment niet als een opdracht zien, maar als een zinvolle manier om na te gaan of hun ideeën kloppen. De uitkomsten van het experiment moeten zorgvuldig worden geëvalueerd om te bekijken of de conclusie die de patiënt heeft getrokken, wel terecht is. Hoewel depressieve patiënten in het algemeen vooraf onderschatten wat ze aankunnen, zijn ze achteraf sterk geneigd achteraf hun prestaties te diskwalificeren: 'Dat kan toch iedereen? Wat stelt het voor?' Door de uitkomsten van het experiment in het licht van de oorspronkelijke vraagstelling te plaatsen wordt de aandacht gericht op wat wél gelukt is.

\section{Negatieve zelfopvattingen en hoge eisen}

Depressieve patiënten hebben vaak negatieve attitudes over zichzelf en stellen vaak hoge eisen. Zij laten hun waarde als persoon vaak afhangen van externe factoren: van wat (zij denken dat) anderen van hen vinden, van de waardering die zij krijgen van anderen of van de prestaties die zij leveren. Vaak vergelijken zij zichzelf daarbij met anderen waardoor zij, door een gekleurde 
interpretatie van de werkelijkheid, steeds als de 'mindere' uit de bus komen. Het bewijs voor hun negatieve attitude vinden patiënten in allerlei gebeurtenissen, zoals voor de attitude: 'Als iemand mij niet moet, dan komt dat doordat ik niet deug.'

Attitudes kunnen op verschillende manieren geïdentificeerd worden. Zo kunnen de gedachteformulieren een belangrijke rol spelen bij het ontdekken van een thematische rode draad in moeilijke situaties. Dagboeken waarin thema's als mislukken en minderwaardig zijn centraal staan, kunnen bijvoorbeeld helpen om de onderliggende attitude; 'Alleen als je perfect bent, ben je iemand' te identificeren. Het taalgebruik van de patiënt kan aanwijzingen geven over het belang van dit thema, zoals: 'Ik ben waardeloos', 'Dat kan ik toch niet' en 'Niemand vindt mij aardig. Attitudes kunnen ook worden opgespoord met behulp van de DAS versie A (Douma 1991, verkorte versie DAS-A-17; Graaf et al. 2009).

\section{Laura}

Laura heeft in de afgelopen twintig jaar meerdere depressieve episodes doorgemaakt. Ze is drie keer effectief behandeld met antidepressiva. Haar nieuwe huisarts verwees haar dit keer echter door voor CT om 'de onderliggende oorzaken aan te pakken'. In het eerste gesprek kwamen onder meer de volgende life-events naar voren:

- een kritische moeder die Laura voortdurend met haar zus vergeleek;

- een van kinds af aan moeilijke relatie met haar oudere zus die zeer ambitieus was;

- de teleurstelling van haar ouders toen ze niet voor haar eindexamen VMBO was geslaagd.

Laura heeft haar hele leven al een laag gevoel van eigenwaarde. Zij heeft voortdurend het gevoel niet goed genoeg te zijn, ongeacht wat ze bereikt in haar leven. Ze is constant kritisch op zichzelf, op wat ze presteert, op haar uiterlijk en op het feit dat ze zich al zoveel jaren depressief voelt. Ze moet van zichzelf aan hoge verwachtingen voldoen: ze moet de perfecte huisvrouw, dochter, echtgenote en moeder zijn. Ze heeft het idee in al haar rollen te falen. In vrijwel alle situaties die in de eerste sessies aan de orde komen is haar conclusie dezelfde: 'Ik ben niet goed genoeg.' In eerste instantie probeert de therapeut samen met Laura tot een meer realistische evaluatie van de besproken situaties te komen. Hiermee wordt onder meer bereikt dat Laura enige afstand kan nemen van deze negatieve zelfbeoordelingen. Daarna gaat de therapeut samen met Laura op zoek naar de ontstaansgeschiedenis van dit negatieve zelfbeeld. Laura herinnert zich dan een aantal momenten vroeger thuis waarin ze van haar moeder sterk het gevoel kreeg niet goed genoeg te zijn. Ze kan zich heel precies een paar situaties voor de geest halen waarbij sterke gevoelens van verdriet en boosheid naar boven komen. De situaties worden vervolgens uitvoerig besproken, onder meer vanuit het perspectief van nu.

Laura beseft ook hoe ze voortdurend bezig is om maar aan de verwachtingen van anderen te voldoen, ook aan die van haar kritische echtgenoot. De onderliggende attitude wordt als volgt geformuleerd: 'Als ik niet aan de verwachting van anderen voldoe maar doe wat ik zelf wil, zullen ze me afwijzen.' Deze attitude heeft geleid tot de perfectionistische eisen waaraan ze moet voldoen. Vervolgens wordt de aandacht gericht op haar eigen verwachtingen, wensen en behoeftes. Ze ontdekt dat ze niet meer goed weet wat ze zelf wil en wat haar behoeftes zijn. Bovendien roept de bewustwording van je gedragen volgens wat je wilt in plaats van wat je moet, de angst op om egoïstisch te zijn en een persoon te worden die eist dat anderen doen wat zij wil. 
In de behandeling van Laura zijn verschillende technieken gebruikt. We bespreken er hier twee. Laura vindt zichzelf onder meer een slechte moeder. De continuümtechniek met concrete criteria is een effectief hulpmiddel om dergelijke attitudes te onderzoeken:

\section{Laura - vervolg}

De globale oordelen die Laura gebruikt ('goede' moeder tegenover 'slechte' moeder) worden hierbij op de uiteinden van een lijn geplaatst. Vervolgens wordt Laura gevraagd zichzelf op deze lijn te plaatsen. De globale oordelen worden daarna uitgedrukt in concrete gedragingen (subdimensies). Deze dimensies scoort Laura eerst voor zichzelf en vervolgens voor twee andere personen, iemand die ze een goede moeder vindt en iemand die ze een slechte moeder vindt (haar schoonmoeder). Ten slotte geeft ze zichzelf opnieuw een plaats op de hoofddimensie (•fig. 4.7).

Door haar het begrip 'goede en slechte moeder' te laten onderzoeken met de continuümtechniek (meerdimensionaal te evalueren), kan Laura op een meer genuanceerde wijze naar haar eigen opvatting kijken en worden haar hoge eisen en verwachtingen zichtbaar. Het uitdrukken van dimensies in concrete gedragingen levert bovendien vaak richtlijnen op voor gedragsveranderingen. Laura ontdekte bijvoorbeeld dat ze in een aantal situaties te weinig grenzen stelt aan het gedrag van haar kinderen. De oorspronkelijke conclusie naar aanleiding van die situaties ('Ik ben een slechte moeder'), kon daarmee veranderd worden in een bewerkbaar probleem.

Een belangrijk probleem van Laura is uiteraard haar negatieve zelfbeeld. Er bestaan een aantal technieken om hierop in te gaan $(\triangleright \mathrm{H} .3,7$ en 11$)$. In de beschreven behandeling heeft de therapeut een techniek gevolgd die we hier kort zullen beschrijven:

\section{Laura - vervolg}

Als eerste wordt de kern van Laura's negatieve zelfbeoordelingen benoemd ('Ik ben niet goed genoeg'). De therapeut stimuleert haar daarna om aspecten van zichzelf te benoemen die met deze opvatting in tegenspraak zijn (Klopt het eigenlijk wel wat je over jezelf denkt? Ben je altijd niet goed genoeg? In alle opzichten?). Vervolgens legt de therapeut de rationale uit ('Je bent te zeer gericht geraakt op het idee niet goed genoeg te zijn en vergeet daarbij situaties waaruit het tegendeel blijkt. Het is belangrijk om deze positieve aspecten van jezelf meer in je zelfbeoordeling te betrekken'). Hij vraagt haar een betoog te schrijven waarin aspecten van goed genoeg zijn prominent aan de orde komen. Het is handig om hier bijvoorbeeld de metafoor van de advocaat in de rechtbank te gebruiken. Die benadrukt immers de goede kanten van zijn patiënt en voert verzachtende omstandigheden aan voor de slechte kanten. Daarna vraagt de therapeut Laura een beeld te beschrijven aan de hand van haar opstel, waarin bij uitstek aspecten van wél goed genoeg zijn blijken. Hij laat haar dit beeld visualiseren. Als laatste stap stelt de therapeut Laura voor om een aantal visualisatieoefeningen te doen. Deze oefeningen worden in de sessie uitgevoerd, maar het is de bedoeling dat ze deze gaat toepassen in actuele situaties waarin de negatieve zelfbeoordelingen zich de komende tijd voordoen. Daarbij is het raadzaam dat de patiënt ook een lichaamshouding en gelaatsuitdrukking aanneemt, die passen bij goed genoeg en zelfverzekerd zijn. 


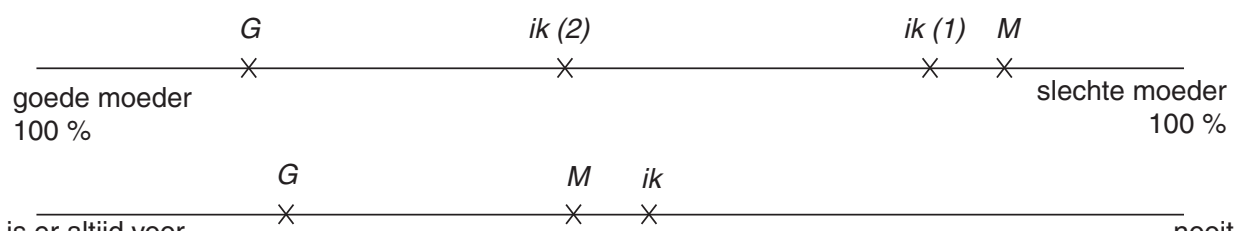

is er altijd voor

$\times \quad X \quad X$ nooit de kinderen

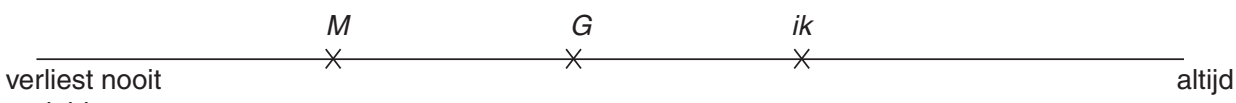
geduld
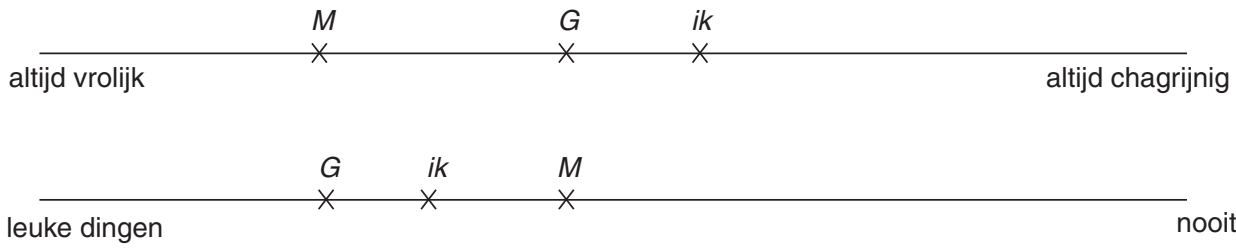
doen met de kinderen
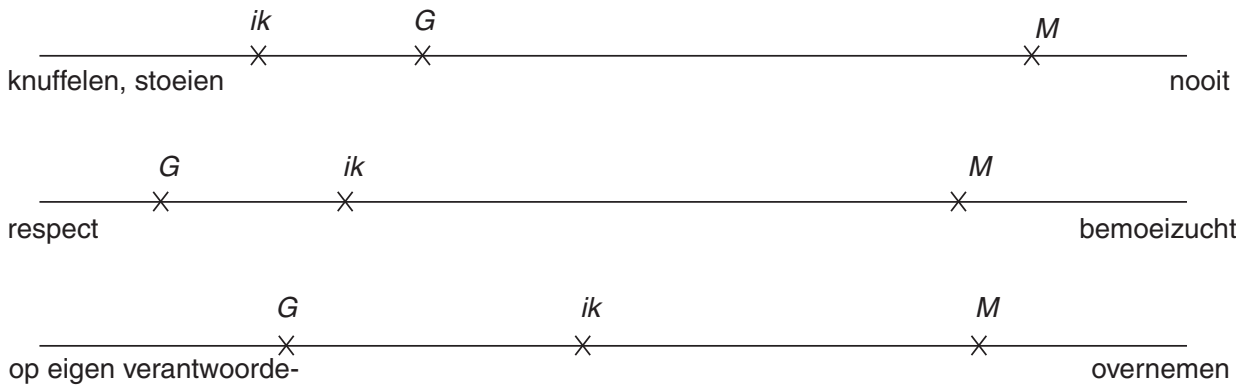
lijkheden wijzen
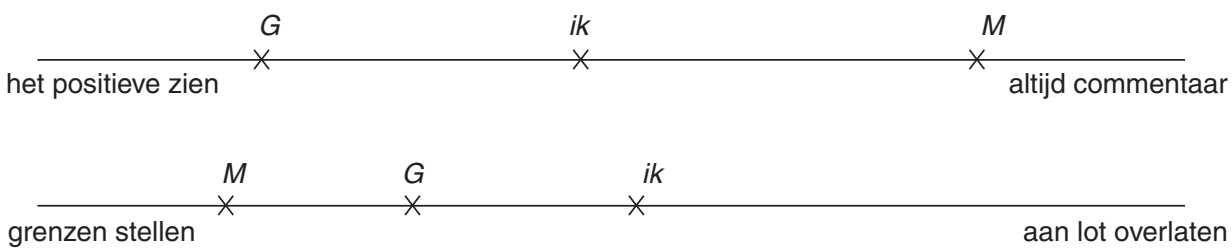

- Figuur 4.7 Zelfbeoordeling van Laura op het continuüm goede moeder-slechte moeder en op de concrete criteria. ( $M$ = slechte moeder, $G=$ goede moeder, ik = Laura, ik (1) = zelfbeoordeling voor de analyse, ik (2) = zelfbeoordeling na de analyse.)

\section{Verantwoordelijkheid en schuld}

In de zelfkritiek van depressieve patiënten zit vaak een element van verantwoordelijk zijn en schuld. Depressieve mensen hebben de neiging om zich overmatig verantwoordelijk te voelen voor negatieve gebeurtenissen ('het is mijn schuld dat het misliep') of voor het gedrag van andere mensen (personaliseren).

Schuldgevoelens zijn veelvoorkomende symptomen van een depressie en zijn vaak gekoppeld aan gevoelens van minderwaardigheid of waardeloosheid. De patiënt heeft het idee in alles te falen en alles te verpesten. Hij vindt zichzelf minderwaardig aan anderen en heeft de neiging om alles wat hij doet en wat hij in het verleden gedaan heeft, in een negatief daglicht te 
stellen. Hij maakt zichzelf verwijten dat hij een slechte partner is, een mislukte ouder, een falende werknemer. Hij voelt zich schuldig omdat hij vindt dat hij in alles tekortschiet. Als de depressie voortduurt, kan hij zichzelf verwijten maken over zaken die vroeger verkeerd gegaan zijn. Kleine gebeurtenissen worden nu gezien als grote fouten of mislukkingen.

In bijzondere omstandigheden, zoals bij het overlijden van een naaste, is het soms moeilijk uit te maken of het zelfverwijt bij een depressie hoort. Ook zonder depressief te zijn maken mensen zich onder deze omstandigheden vaak verwijten die passend zijn bij een rouwreactie. Als deze schuldgevoelens echter een overmatig karakter aannemen, als ze bijvoorbeeld blijven toenemen, dan is er waarschijnlijk sprake van depressieve schuldgevoelens.

Schuldgevoelens zijn soms deels gebaseerd op het daadwerkelijk tekortschieten van de depressieve patiënt. Op het werk functioneert hij inderdaad minder goed, de huishouding wordt daadwerkelijk verwaarloosd en de kinderen krijgen objectief gezien minder aandacht sinds hij depressief is. Hoewel dit tekortschieten het gevolg is van de depressie, wordt dit door de patiënt vaak niet zo gezien. Deze beschouwt het in de regel niet als een consequentie van de depressie, maar opnieuw als een persoonlijk falen.

Veelgebruikte technieken voor overmatige verantwoordelijkheidsgevoelens en schuldgevoelens zijn:

- Dubbele standaard aantonen: hierdoor kan de patiënt inzien dat aan het eigen gedrag veel hogere eisen gesteld worden dan aan dat van anderen. ('Als iemand anders dat zou overkomen, zou je hem dan ook zo veroordelen?').

- Het taartdiagram (zie verder).

Bij het taartdiagram (•fig. 4.8 en $>$ H. 3) worden de volgende stappen gezet:

- Bepaal de negatieve gebeurtenis of uitkomst waarvan de patiënt zichzelf de schuld geeft.

- Maak een lijst van alle mogelijke redenen waarom deze gebeurtenis plaatsvond met inbegrip van de eigen rol van de patiënt, de rol van anderen en de rol van de situatie. Houd ook rekening met pech, toeval of onbekende oorzaak. Als de patiënt het moeilijk vindt andere verklaringen te vinden, laat hem dan de rol van z'n eigen advocaat spelen die nieuwe invalshoeken voor de situatie moet aandragen.

- Geef voor elk van de verklaringen een waarschijnlijkheidsscore in percentages. Alle interpretaties bij elkaar opgeteld moeten een $100 \%$-verklaring vormen voor de gebeurtenis. Begin het scoren van de alledaagse verklaring en laat de patiënt zichzelf pas als laatste scoren. Ga door tot een totaal van $100 \%$ is bereikt en de patiënt het gevoel heeft dat de toegekende percentages kloppen.

- Geef de diverse percentages van de interpretaties weer in een taartpuntdiagram.

- Bespreek de resultaten in het licht van de oorspronkelijke interpretatie en laat de patiënt conclusies trekken.

\section{Saskia}

Saskia is erg somber na het kinderfeestje ter gelegenheid van de verjaardag van haar zoontje: 'Het is mijn schuld dat het feestje mislukt is.' Bij de bespreking van de gebeurtenissen worden met name haar alles-of-niets-conclusie met betrekking tot de schuldvraag ter discussie gesteld. Aan de hand van de stappen van de taartdiagramtechniek wordt vervolgens een lijstje gemaakt van alle mogelijke oorzaken voor de gang van zaken op het feestje. Uiteindelijk ziet het lijstje er als volgt uit: 
- De cupcakes waren verbrand. Zoontje had per ongeluk haar kookwekker uitgezet toen hij met haar telefoon speelde. Hierdoor merkte Saskia pas te laat dat ze de cakejes uit de oven moest halen (1\%).

- Er waren een paar vervelende kinderen op het feestje. Kinderen die schreeuwden en die niets leuk vonden (10\%).

- Het regende de hele middag waardoor Saskia haar plannen moest omgooien en ze zich moesten vermaken in de veel te kleine huiskamer (39\%).

- Een van de moeders die zou komen helpen, kwam niet opdagen (25\%).

- Een paar ouders haalden hun kinderen veel later op dan was afgesproken (5\%).

- Eigen aandeel (20\%).

De percentages worden vervolgens in een taartdiagram gezet (•fig. 4.8) en samen wordt gereflecteerd op mogelijke conclusies.

Soms maken patiënten zichzelf verwijten over gebeurtenissen waarmee zij moeilijk in verband gebracht kunnen worden. Zo is het zeer onwaarschijnlijk dat de patiënt de oorzaak is van natuurrampen of andere ellende in de wereld. Als een patiënt ervan overtuigd is een dergelijke gebeurtenis toch op zijn geweten te hebben, dan is er waarschijnlijk sprake van een depressie met psychotische kenmerken.

\section{Verlieservaringen}

Depressieve patiënten hebben over het algemeen sterk de neiging om te kijken naar wat ze niet (meer) hebben. Verlieservaringen spelen een belangrijke rol in het ontstaan en de instandhouding van depressieve klachten. Beck (1987) beschouwt gevoelens met betrekking tot falen en verlies als de voornaamste gevoelens van een depressie. Verlieservaringen hebben doorgaans betrekking op verlies van personen, status of eigenwaarde. Volgens Beck (1987) zijn sommige mensen kwetsbaarder voor verliezen in het domein van relaties, en anderen meer in het domein van prestaties en onafhankelijkheid.

Niet iedereen wordt depressief na een verlieservaring. Wat zijn nu de factoren die het risico op een depressie verhogen? Volgens de cognitieve theorie vertonen alle depressieve patienten, als ze eenmaal depressief zijn, dezelfde negatieve cognities. Maar in de route naar het begin van een (reactieve) depressie speelt een aantal samenhangende factoren een rol. Beck (1987) gaat ervan uit dat een depressieve stoornis het resultaat is van de interactie tussen:

- disfunctionele opvattingen over de betekenis van bepaalde ervaringen;

- het toekennen van grote waarde aan het belang van de ervaring;

- de aanwezigheid van een relevante stressor;

$=$ persoonlijkheidsstijl.

Volgens Beck (1987) is een tweetal persoonlijkheidsstijlen te onderscheiden die beschouwd kunnen worden als kwetsbaarheidsfactor voor het ontstaan van een depressie: de afhankelijke/ sociotropische persoonlijkheidsstijl en de autonome persoonlijkheidsstijl. Deze persoonlijkheidsstijlen zijn te situeren op de uiteinden van een continuüm. Zij bepalen in hoge mate de waarde die aan het belang van ervaringen wordt toegekend en het soort stressor dat disfunctionele opvattingen kan activeren.

Aan de ene pool is er de kwetsbaarheidsfactor van de afhankelijkheid of sociotropie. Dit verwijst naar mensen die overmatig afhankelijk zijn van liefde, waardering en acceptatie van anderen. Zij stellen zich overmatig afhankelijk op van de omgeving. Zij verwachten 


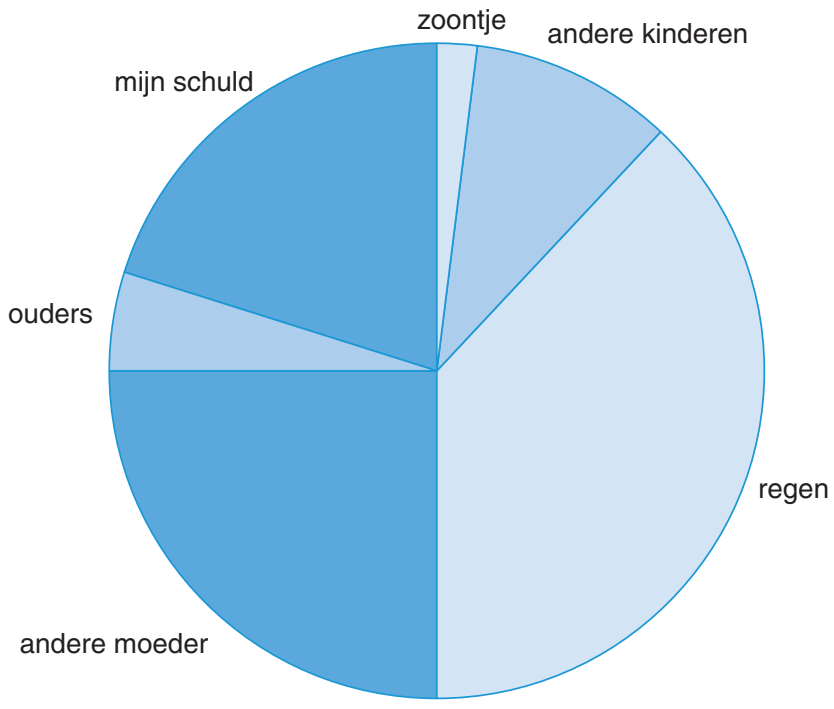

- Figuur 4.8 Taartdiagram van de gedachte: het is mijn schuld dat het feestje is mislukt

voortdurend ondersteuning en bevestiging. Hun zelfbeeld laten ze afhangen van de waardering die ze krijgen van anderen. Hun probleemoplossende vaardigheden zijn vaak gering en ze schatten hun interpersoonlijke vaardigheden laag in. Deze personen zijn gevoelig voor lifeevents op het gebied van persoonlijke relaties. Erbij horen is voor hen een belangrijk thema. Ze zijn dan ook kwetsbaarder voor depressie bij verlies, conflicten (dreigend verlies) en afwijzing.

De andere pool omvat de kwetsbaarheidsfactor van zelfkritisch perfectionisme en autonomie. Deze personen zijn zeer kritisch naar zichzelf, stellen perfectionistische eisen aan hun prestaties en presenteren zich zeer zelfstandig. Ze zijn echter uiterst gevoelig voor kritiek die ze snel op zichzelf betrekken. Ze houden zich vooral bezig met de mogelijkheid van falen en trachten doorgaans de controle op de omgeving te maximaliseren om de kans op falen en kritiek te verminderen. Deze personen zijn gevoelig voor negatieve life-events die hun sterke doelgerichtheid in de weg staan. Prestaties leveren is voor hen een centraal thema. Als dat niet lukt, gaan ze gebukt onder hevige zelfkritiek.

Als een verlieservaring eenmaal tot een depressie heeft geleid, gaat dit gepaard met een negatieve kijk op de huidige levenssituatie ('Mijn leven is totaal verwoest'), op de toekomst ('Het is hopeloos, ik word nooit meer gelukkig') en op de patiënt zelf ('Ik heb gefaald').

\section{Robert}

Robert was jarenlang senior partner bij een gerenommeerd advocatenkantoor. Hij deed zijn werk met veel plezier. Dit veranderde echter toen er een nieuwe partner toetrad tot het bedrijf. De sfeer veranderde en er ontstonden veel conflicten. Toen Robert de kans kreeg om met vervroegd pensioen te gaan, heeft hij deze gegrepen en zijn aandeel verkocht. In het begin was hij opgelucht, maar al snel begon hij te twijfelen. Wie was hij eigenlijk nu hij geen advocaat meer was? En hoe moest hij zijn leven nu gaan inrichten? Toen het hem niet zo snel lukte om een nieuwe daginvulling te vinden, begon hij sterk te twijfelen aan zichzelf, en raakte hij ervan overtuigd gefaald te hebben en niets meer waard te zijn. Hij voelt zich onzeker onder de mensen en is sterk geneigd zich terug te trekken. De toekomst ziet hij met somberheid tegemoet. 
In de behandeling van Robert werd veel aandacht besteed aan de gebeurtenissen rondom zijn pensioen en werden de conclusies die hij getrokken had over zichzelf, zijn leven en de toekomst op socratische wijze uitgedaagd. Hierdoor ging hij zich onder meer realiseren dat hij voor zijn pensioen een veel positiever en genuanceerder beeld van zichzelf had ('Ik ben goed in mijn werk, maar heb ook veel andere kwaliteiten'). Dit inzicht had een positief effect op zijn stemming. Bovendien maakte het de weg vrij om te bespreken wat de mogelijkheden (of zelfs de voordelen) van de nieuwe situatie zijn: hij kon nu veel meer tijd doorbrengen met de kleinkinderen, die hij vanwege zijn drukke baan eerder nauwelijks had zien opgroeien.

\section{Rouw en depressie}

Rouwen na een verlieservaring is noodzakelijk om het verlies te kunnen verwerken. Doorgaans is rouw na het verlies van een dierbare geen reden om in therapie te gaan. In de meeste gevallen doet de tijd zijn werk. Een normaal rouwproces kent een aantal fasen waarin verschillende emoties en gedachten een rol spelen:

1. Na een verlies komt de persoon gewoonlijk in een toestand van verdoving. Hij realiseert zich nog niet ten volle wat er eigenlijk gebeurd is.

2. Daarna volgt een reactie van ongeloof of ontkenning. Hij veronderstelt dat de situatie zich niet heeft voorgedaan of dat de situatie op een of andere manier nog ongedaan gemaakt kan worden.

3. Vervolgens ervaart hij woede en verzet. Hij voelt zich slachtoffer van een onrechtvaardig lot.

4. Dan volgt de fase van gevoelens van wanhoop en verdriet. De volle betekenis van het verlies dringt door, evenals het besef van de onomkeerbaarheid ervan.

5. Ten slotte komt hij in de fase van integratie en het openstaan voor nieuwe banden.

Het is van belang om onderscheid te maken tussen de depressieve gevoelens bij rouw en een depressieve stoornis. Hoewel het niet gemakkelijk is om dit onderscheid te maken, kan aan rouw gedacht worden wanneer:

- er vooral sprake is van gevoelens van leegte en niet zozeer van anhedonie;

- de somberheid geen weken of maanden achter elkaar aanhoudt;

- de sombere gedachten sterk gerelateerd zijn aan de overledene;

- het gevoel van eigenwaarde intact is gebleven;

- de schuldgevoelens zich beperken tot het verlies van de dierbare;

- er geen sprake is van langdurend onvermogen om de normale dagelijkse taken en activiteiten te vervullen.

Wanneer de symptomen van rouw echter gedurende enkele maanden in ernstige mate voortduren en er sprake is van onvermogen om normaal te functioneren, is het raadzaam te onderzoeken of er (inmiddels) toch niet sprake is van een depressie. Er bestaat geen 'vastgestelde' tijd voor een normaal rouwproces.

Daarnaast dient 'normale' rouw onderscheiden te worden van complexe rouw. Bij normale rouw neemt de intensiteit na verloop van tijd geleidelijk af. Hoewel er geen 'vastgestelde' tijd bestaat voor een normaal rouwproces, zijn de meeste mensen in het algemeen na ongeveer zes maanden weer in staat om hun leven enigszins op te pakken. Bij complexe rouw lukt dat echter niet en is iemand in een van de eerste vier fasen blijven steken, waardoor de symptomen maanden of zelfs jaren voortduren. In dat geval spreekt men van een persisterende complexe rouwstoornis. Deze aandoening is in de DSM-5 opgenomen in de sectie 'aandoeningen die verder onderzoek behoeven'. 
Het onderscheid tussen de depressieve gevoelens bij rouw en een depressieve stoornis is van belang omdat de focus van de behandeling anders ligt. Bij een (normaal of complex) rouwproces wordt de behandeling gericht op de verlieservaring. In principe worden de genoemde fasen van een rouwproces daarbij als uitgangspunt genomen. De therapeut dient in de behandeling voornamelijk alert te zijn op schuldgevoelens ('Ik had het kunnen voorkomen, ik had meer moeten doen') en op gevoelens van hopeloosheid ('Ik kom er nooit meer uit, ik word nooit meer gelukkig'). Ook wordt er veel aandacht besteed aan de relatie met de overledene en aan de betekenis van het verlies voor de patiënt. De therapeut helpt de patiënt om de veranderde realiteit onder ogen te zien en om met de daarbij behorende gevoelens om te gaan. Hij helpt de patiënt weer in het heden te leven in plaats van in het verleden. Ten slotte wordt de aandacht gericht op het vinden van een nieuw perspectief, zodat er weer hoop kan ontstaan.

\subsection{Valkuilen}

Een belangrijke kenmerkende valkuil voor mensen met een depressie is de negatieve terughoudende attitude. De meeste patiënten hebben deze ook ten aanzien van de behandeling, zeker in het begin. Het is van belang hoop te geven, maar de therapeut moet proberen te voorkomen dat hij als een vertegenwoordiger de patiënt probeert te overtuigen. Dit is mogelijk door terug te geven dat je bijvoorbeeld blij bent met de kritische houding of de terughoudendheid van de patiënt en dat je het voldoende acht als de patiënt de aanpak de eerste vijf tot zeven weken een kans wil geven. Na die periode volgt een tussentijdse evaluatie.

Daarnaast gaat depressie vaak gepaard met moeheid en interesseverlies. De patiënt geeft aan tot niets te komen, dus ook niet tot huiswerk. De therapeut dient bij het opgeven van het huiswerk in te schatten of deze taak voor de patiënt haalbaar is. In plaats van te vragen de hele week de stemming en gedachten te registreren, kan het zinnig zijn dit in eerste instantie te beperken tot een dagdeel. Het is zinvol daarbij goed na te vragen welk moment van de dag het beste uitkomt, rekening houdend met alle mogelijke denkbare belemmeringen. Wanneer het desondanks nog steeds niet lukt om het huiswerk (voldoende) uit te voeren, is het belangrijk dat er wordt bekeken wat daarvoor de redenen zijn geweest. Daarbij dient de therapeut eerst na te gaan of de instructies duidelijk waren en de patiënt ze heeft onthouden. Heeft de therapeut er bijvoorbeeld op toegezien dat de patiënt de huiswerkinstructies heeft genoteerd? Huiswerkproblemen kunnen daarnaast te maken hebben met de moeilijkheidsgraad van het huiswerk (te moeilijk of te veel), met angst om te falen ('Ik kan het niet'), of met de angst dat de depressie erger wordt als er aandacht aan wordt besteed. Regelmatig worden patiënten wanhopig bij het idee dat ze iets moeten registreren, met als gevolg dat ze hun registratie niet uitvoeren. Probeer met de patiënt te achterhalen of er sprake was van deze wanhoop, bespreek waardoor deze wanhoop toesloeg, en zoek samen naar mogelijkheden om het proces te vergemakkelijken: helpt het om eerst eens alleen gedachten en gevoelens op te schrijven, of om de informatie in te spreken in plaats van op te schrijven?

Verder is het voor depressieve patiënten zo kenmerkende perfectionisme ook een mogelijke valkuil bij de uitvoering van huiswerkopdrachten: 'Ik moet het perfect doen, anders is het zinloos.' Angst voor een negatieve beoordeling door de therapeut kan eveneens een rol spelen. In het geval van perfectionisme of angst voor negatieve beoordeling van de therapeut worden de daarmee verbonden disfunctionele cognities geëxploreerd en uitgedaagd. In dergelijke gevallen kan het ook helpen om de huiswerkopdrachten niet zelf te bekijken, maar deze bij de patiënt te laten en hem te vragen om de strekking ervan te bespreken. 
De ernst van de depressie kan tevens een belemmering vormen bij de uitvoering van de CT. Bij patiënten met een ernstige depressie kan het negatieve denken zo overheersend zijn en de apathie zo groot dat het uitvoeren van huiswerkopdrachten lastig is. Ook bij ernstige depressies is CT effectief, maar niet in alle gevallen kan de therapeut in het begin van de behandeling standaard huiswerkopdrachten meegeven (Hollon et al. 2005). In zulke gevallen is het ook mogelijk te starten met het maken van de huiswerkopdrachten binnen de sessie. In een klinische setting kan een verpleegkundige gevraagd worden om de patiënt daarbij te ondersteunen.

Bij het evalueren is de minder complexe methode van het zoeken van bewijzen voor en tegen de negatieve gedachte ( $\bullet$ H.2) aan te bevelen. Daarnaast is het raadzaam de behandeling langzamer op te bouwen, bijvoorbeeld te starten met leren differentiëren in gevoel, in plaats van het leren differentiëren van situatie, gedachte en gevoel. Verder is het zinvol om de behandeling ook te richten op herstel van het activiteitenniveau en om gedragsmatige interventies in te zetten. Een verhoging van het activiteitenniveau leidt bij de meeste patiënten al tot een stemmingsverbetering, waardoor de CT beter uitvoerbaar wordt.

Hopeloosheid komt veel voor bij depressie en is tevens een voorspeller van suïcidaliteit. Het is van belang hier regelmatig naar te vragen. De therapeut kan de patiënt herhaaldelijk laten weten dat diens problemen niet onoplosbaar zijn ofwel dat de depressie kan opklaren. In geval van doodsgedachten kan het helpend zijn deze te kaderen als een symptoom van de depressie. De therapeut kan expliciet benoemen dat de gedachten ontstaan zijn door de depressie en dat ze dus ook weer kunnen weggaan wanneer de depressie opklaart. Het is daarnaast van belang om alert te zijn op de overdracht van hopeloosheid naar de therapeut of het behandelend team in de kliniek. Veel depressieve patiënten kunnen zo overtuigend zijn in het overdragen van de hopeloosheid, dat ook de therapeut begint te geloven dat de situatie uitzichtloos is. Dit laatste komt met name veel voor bij persisterende depressie of als er sprake is van complexe problematiek.

Het (herhaaldelijk) motiveren van de patiënt voor de behandeling in zijn totaliteit en voor het uitvoeren van huiswerkopdrachten stelt bij depressieve patiënten extra eisen. De wijze waarop de therapeut de huiswerkopdrachten brengt en omgaat met 'moeilijk' gedrag van de patiënt, bepaalt voor een belangrijk deel het verloop van de behandeling. Lange (1990) noemt een aantal motiveringstechnieken die de therapeut ter beschikking staan en die goed bij depressieve patiënten toegepast kunnen worden. Met name het geven van hoop is zeer belangrijk bij depressieve patiënten. Daarnaast kan het verstandig zijn een judotechniek te gebruiken om een machtsstrijd te voorkomen indien congruente methoden niet aanslaan.

Bij de uitvoering van cognitieve interventies bij depressieve patiënten kan zich verder een probleem voordoen als de therapeut in plaats van socratische vragen te stellen (en het aanleren deze socratische vragen aan zichzelf te stellen), de patiënt gaat overtuigen of de discussie aangaat met patiënten over hun opvattingen. Iets dergelijks gebeurt als de therapeut zelf de bewijzen gaat leveren voor de onjuistheid van de ideeën van de patiënt. Deze valkuil is levensgroot aanwezig bij depressieve patiënten, die vaak stil en wanhopig zijn of veel huilen tijdens een sessie.

Te snel willen starten met het evalueren of toetsen van gedachten is een andere valkuil voor de therapeut. Sommige depressieve patiënten zijn vermijdend ten aanzien van de eigen negatieve gedachten en gevoelens, en hebben veel moeite hierbij stil te staan. Dit lijkt aanvankelijk niet zo; depressieve patiënten hebben immers erg veel negatieve gedachten. Maar vaak is deze vorm van rumineren een vorm van vermijding, dat wil zeggen dat men bij geen enkele 
negatieve gedachte echt stilstaat. Zodoende starten patiënten zelf soms ook graag te snel met uitdagen, voordat ze zich bewust zijn geworden van de wijze waarop zij de werkelijkheid vertekend waarnemen. De evaluatie blijft zich dan op een rationeel niveau afspelen, zonder emotionele veranderingen. Het is zaak hier alert op te zijn en de patiënt te leren stilstaan bij negatieve gedachten en gevoelens.

\subsection{Therapie-effectstudies}

Cognitieve therapie is de meest onderzochte vorm van psychotherapie bij depressie. De resultaten van onderzoek naar de effectiviteit van cognitieve (gedrags)therapie voor volwassenen met een depressie zijn samengebracht in de Multidisciplinaire Richtlijn Depressie (Spijker et al. 2013). Hier concludeert men dat cognitieve (gedrags)therapie een effectieve psychotherapeutische behandeling is voor de depressieve stoornis, zowel in de acute fase als daarna. Cognitieve (gedrags)therapie is eveneens effectief bij persisterende depressie, al zijn de effecten wel minder groot dan bij de niet-chronische variant. Daarnaast zijn er bij persisterende depressie mogelijk meer sessies nodig.

Voor specifieke psychotherapievormen die gericht zijn op persisterende chronische depressie, zie Wiersma et al. (2015).

CGT is niet alleen effectief bij depressieve volwassenen, maar ook bij ouderen (Cuijpers et al. 2011), en kinderen en adolescenten (zie voor een overzicht o.a. Weisz et al. 2006; Zhou et al. 2015). Uit een systematische review van Churchill en collega's (2001) en een meta-analyse van Cuijpers en Dekker (2005) bleek dat individuele CGT effectiever is dan groepscognitieve gedragstherapie. Dit werd niet gevonden in een meta-analyse bij ouderen (Cuijpers et al. 2006).

Ook cognitief gedragstherapeutische programma's die worden aangeboden via internet (e-health) kunnen effectief zijn in het verminderen van depressieve klachten. Dit is het geval voor zowel zelfhulpprogramma's als voor programma's waarbij op afstand een professional is betrokken (bijvoorbeeld via e-mail, chat of skype; Blankers et al. 2013; Karyotaki et al. 2017). Er zijn echter aanwijzingen dat de effecten van programma's waar een therapeut bij betrokken is, groter zijn dan die van programma's die patiënten volledig zelfstandig moeten doorlopen (Spek et al. 2007). De effecten van 'blended' behandelingen - waarbij e-health-sessies worden afgewisseld met face-to-face contacten met de therapeut - worden momenteel volop onderzocht (o.a. Kemmeren et al. 2016; Kooistra et al. 2014). Vooralsnog lijken zij echter niet duidelijk effectiever dan traditionele face-to-face behandelingen (Kenter et al. 2015).

Bij het interpreteren van deze bevindingen dient rekening gehouden te worden met het feit dat de effecten van psychologische interventies vanwege publicatiebias (met name positieve studies werden gepubliceerd) zijn overschat, al zijn de effecten na correctie voor publicatie nog steeds groot genoeg om te spreken van een klinisch relevant effect (Driessen et al. 2015).

Er zijn geen consistente indicaties en contra-indicaties voor cognitieve (gedrags)therapie bij depressie. Vanwege deze effecten behoort cognitieve (gedrags)therapie momenteel tot de aanbevolen psychologische standaardzorg voor depressie in Nederland. In de volgende paragrafen vergelijken we de effecten van cognitieve (gedrags)therapie met die van antidepressiva en andere psychologische behandelingen voor depressie. 


\subsubsection{Cognitieve (gedrags)therapie versus antidepressiva}

De acute effecten van cognitieve (gedrags)therapie zijn vergelijkbaar met die van antidepressieve medicatie (Cuijpers et al. 2011). Bij milde en matige depressies verdient cognitieve (gedrags)therapie zelfs de voorkeur boven antidepressiva. Bij ernstige, chronische en recidiverende depressie is cognitieve (gedrags)therapie even effectief als medicatie. In dat geval lijkt een combinatiebehandeling van cognitieve (gedrags)therapie met antidepressiva het meest effectief (Cuijpers et al. 2010; Spijker et al. 2013). Hollon en collega's (2014) onderzochten de effecten van een combinatiebehandeling van cognitieve (gedrags)therapie met antidepressiva en vonden dat de combinatiebehandeling tot betere behandelresultaten leidde dan medicatie alleen, voornamelijk bij patiënten met een ernstige (niet-chronische) depressie. Bovendien was er minder drop-out. Indien na de behandeling met antidepressieve medicatie nog restsymptomen aanwezig zijn, wordt vervolgbehandeling ter preventie van terugval met cognitieve (gedrags)therapie aanbevolen (Bockting et al. 2015).

Op de lange termijn kent cognitieve (gedrags)therapie een lager terugvalpercentage dan antidepressieve medicatie (Cuijpers et al. 2013b; Hollon et al. 2005; Vittengl et al. 2007). Mogelijk is dit profylactische effect (dat wil zeggen een voortdurende beschermende werking na het beëindigen van de therapie-uitleg) te verklaren doordat men de bereikte verbetering bij psychotherapie aan eigen inspanningen toeschrijft, terwijl in geval van medicatie de verbetering aan de medicatie toegeschreven wordt. Dit verklaart echter niet waarom cognitieve (gedrags)therapie ook lagere terugvalcijfers laat zien dan voortgezette medicamenteuze (onderhouds)behandeling. Een andere verklaring is daarom dat cognitieve (gedrags) therapie patiënten inzichten geeft en vaardigheden aanleert, die er niet alleen voor zorgen dat iemand beter wordt, maar ook beter blijft. Indien Preventieve Cognitieve Therapie (PCT) en Mindfulness Based Cognitieve Therapie (MBCT) gestart wordt na herstel van terugkerende depressie reduceert dat het risico op terugval substantieel (o.a. Bockting et al., 2015, 2018).

Ook bij het interpreteren van deze bevindingen dient rekening gehouden te worden met het feit dat de effecten van antidepressiva vanwege publicatiebias (met name positieve studies werden gepubliceerd) decennialang zijn overschat (Turner et al. 2008). Vooralsnog is het dus lastig om eenduidige uitspraken te doen over het effect van antidepressiva ten opzichte van CGT, rekening houdend met publicatiebias.

\subsubsection{Cognitieve (gedrags)therapie versus andere vormen van psychotherapie}

Ook de effectiviteit van CT ten opzichte van andere psychologische interventies is veelvuldig onderzocht. Barth en collega's (2013) deden een meta-analyse waarin zij 198 studies opnamen die in totaal zeven verschillende vormen van psychotherapie met elkaar vergeleken (o.a. cognitieve therapie, interpersoonlijke psychotherapie, gedragsactivatie, kortdurende psychodynamische therapie en probleemoplossende therapie). Zij concludeerden dat psychotherapie duidelijk effectiever was dan een wachtlijstconditie, maar dat er geen noemenswaardige verschillen waren tussen de diverse vormen van psychotherapie onderling. Deze bevinding is in lijn met een reeks andere meta-analyses waarin de relatieve effecten van psychologische interventies werden bekeken (o.a. Cuijpers et al. 2008, 2011, 2013a, 2014; Hollon en Ponniah 2010).

Interpersoonlijke therapie (IPT) is naast CT de meest onderzochte en toegepaste vorm van psychotherapie voor depressie in Nederland. Gerandomiseerde behandelstudies waarin de acute effecten van beide interventies direct met elkaar worden vergeleken, laten zien dat 
de behandelingen gemiddeld gezien even effectief zijn (zie Jakobsen et al. (2012) en Lemmens et al. (2015) voor een overzicht). Mogelijk zijn er wel verschillen voor bepaalde subgroepen van patiënten. De subgroep van patiënten die in deze studies het vaakst is bekeken, is de groep met een ernstige depressie. De resultaten voor deze groep zijn tegenstrijdig. Elkin en collega's (1989) concludeerden dat mensen met een ernstige depressie het beste behandeld kunnen worden met IPT, terwijl Luty et al. (2007) vonden dat CGT beter was voor deze subgroep. Lemmens et al. (2015) vonden geen verschillen tussen beide interventies.

Hoewel van IPT herhaaldelijk is aangetoond dat het terugval kan voorkomen indien het wordt toegepast als onderhoudstherapie (Cuijpers et al. 2016; Mulder et al. 2017), is er slechts weinig onderzoek voorhanden naar de profylactische effecten van IPT. Lemmens en collega's (2018) volgden patiënten die behandeld waren met CT en interpersoonlijke therapie gedurende zeventien maanden na afloop van hun behandeling. Zij vonden dat patiënten die behandeld waren met interpersoonlijke therapie in deze periode niet vaker terugvielen dan mensen die behandeld waren met cognitieve therapie. Aangezien het profylactische effect van CGT herhaaldelijk is aangetoond door middel van vergelijkingen met ADM, suggereren deze resultaten dat IPT ook profylactische effecten heeft.

Er zijn tevens aanwijzingen dat kortdurende psychodynamische psychotherapie (KPT) een effectieve behandeling is voor depressie (zie meta-analyse van Driessen et al. (2010) voor een overzicht). Een Nederlandse meta-analyse wees uit dat KPT (16 sessies) even effectief is als een behandeling met antidepressiva en dat de combinatie van beide effectiever was de enkelvoudige behandeling (de Maat et al. 2008). Eerdere meta-analyses wezen uit dat psychodynamische psychotherapie inferieur is ten opzichte van cognitieve (gedrags)therapie en IPT (Gloaguen et al. 1998; Svartberg en Stiles 1991). Dit werd echter niet bevestigd door de meta-analyse van Cuijpers en collega's (2008). In een meer recente empirische studie werden wederom geen verschillen gevonden tussen CGT en KPT (Driessen et al. 2013).

Ook het toepassen van enkel gedragsmatige activatie lijkt even effectief als cognitieve interventies (Cuijpers et al. 2007; Richards et al. 2016). Bij ernstig depressieve patiënten is gedragsactivatie mogelijk zelfs effectiever dan CT (Dimidjian et al. 2006).

\section{( Conclusie}

Samengevat kan gesteld worden dat cognitieve (gedrags)therapie de meest onderzochte, effectief bevonden behandeling is voor depressie, die vanwege de profylactische effecten vooralsnog een meerwaarde lijkt te hebben boven antidepressiva (Spijker et al. 2013). Wanneer iemand zonder hulpverleningsgeschiedenis of iemand met een recidiverende depressie hulp zoekt, heeft het de voorkeur cognitieve (gedrags)therapie aan te bieden en alleen wanneer dit niet (voldoende) werkt medicamenteuze behandeling te overwegen; niet alleen vanwege de aangetoonde profylactische effecten van $\mathrm{CT}$, maar ook in verband met attributieeffecten en bijwerkingen van medicatie. Bovendien is het onbekend wat het gebruik van antidepressiva in de zwangerschap en bij borstvoeding heeft op het kind, hetgeen zeer relevant is gezien het grote aantal vrouwen in de leeftijd tussen de 25 en 35 jaar dat behandeling (Brouwer et al., 2018) voor depressie zoekt. Ondanks deze positieve en duurzame effecten van cognitieve (gedrags)therapie profiteert (nog) niet iedereen (voldoende) van de behandeling. Het onderzoek naar het verder verfijnen en uitbreiden van CT voor depressie gaat dan ook verder. Speerpunt in het huidige onderzoek is ontdekken hoe en welke interventies op de lang termijn ook effectief blijken (Bockting et al., 2018). Op deze manier kunnen behandeleffecten verder geoptimaliseerd worden. 


\section{Bijlage 4.1 Dagboekformulier 1: activiteiten}

\begin{tabular}{|l|l|l|l|l|}
\hline datum & tijd & stemming & 'moet'-activiteit & plezierige/ontspannen activiteit \\
\hline & & & & \\
\hline & & & & \\
\hline & & & & \\
\hline & & & & \\
\hline & & & & \\
\hline & & & & \\
\hline & & & & \\
\hline
\end{tabular}

Bron: het formulier komt uit Albersnagel, Emmelkamp en Van den Hoofdakker, 2002

\section{Literatuur}

Abramson, L. Y., Seligman, M. E. P., \& Teasdale, J. (1978). Learned helplessness in humans: Critique and reformulation. Journal of Abnormal Psychology, 87, 49-74.

Alloy, L. B., \& Abramson, L. Y. (1988). Depressive realism: Four theoretical perspectives. In L. B. Alloy (Ed.), Cognitive processes in depression (pp. 223-265). New York: Guilford Press.

American Psychiatric Association (2000). Diagnostic and statistical manual of mental disorders (4th ed.). Washington D.C.: American Psychiatric Association.

American Psychiatric Association (2013). Diagnostic and statistical manual of mental disorders (5th ed.). Arlington: American Psychiatric Publishing.

Arnow, B. A., \& Constantino, M. J. (2003). Effectiveness of psychotherapy and combination treatment for chronic depression. Journal of Clinical Psychology, 59, 893-905.

Barth, J., Munder, T., Gerger, H., Nuësch, E., Trelle, S., Znoj, H., et al. (2013). Comparative efficacy of seven psychotherapeutic interventions for patients with depression: A network meta-analysis. PloS Medicine, 10(5), e1001454.

Beck, A. T. (1967). Depression: Clinical, experimental, and theoretical aspects. New York: Hoeber.

Beck, A. T. (1987). Cognitive models of depression. Journal of Cognitive Psychotherapy: An International Quarterly, 2, 5-37.

Beck, J. S. (2011). Cognitive therapy: Basics and beyond (2nd ed.). New York: Guilford Press.

Beck, A. T., Rush, A. J., Shaw, B. F., \& Emery, G. (1979). Cognitive therapy of depression. New York: Guilford Press.

Blankers, M., Donker, T., \& Riper, H. (2013). E-Mental health in Nederland; Wetenschappelijke evidentie en uitdagingen voor de praktijk. De Psycholoog, 9, 12-23.

Bockting, C. L. H., \& Baas, K. (2010). Kortdurende cognitieve gedragstherapie bij depressie in de eerste lijn. Werkboek. Amsterdam: op te vragen via c.l.bockting@amc.uva.nl.

Bockting, C. L. H., Hollon, S. D., Kuyken, W., Jarrett. R., \& Dobson, K. S. (2015). A lifetime approach to Major Depressive Disorder: The contributions of psychological interventions in preventing relapse and recurrence. Clinical Psychology Review, 41, 16-26. - https://doi.org/10.1016/j.cpr.2015.02.003

Bockting, C. L. H., Spinhoven, P., Koeter, M. W. J., Wouters, L. F., Visser, I., Schene, A. H., \& DELTA-study-group (2006). Differential predictors of response to preventive cognitive therapy in recurrent depression: A 2-year prospective study. Psychotherapy and Psychosomatics, 75, 229-236.

Bockting, C. L. H., Klein, N. S., Elgersma, H. J., van Rijsbergen, G. D., Slofstra, C., Ormel, J., et al. (2018). The effectiveness of preventive cognitive therapy while tapering antidepressants compared with maintenance antidepressant treatment and their combination in the prevention of depressive relapse or recurrence (DRD study): A three-arm randomised controlled trial. Lancet Psychiatry. Advance online publication. https://doi.org/10.1016/S2215-0366(18)30100-7.

Boelens, W., \& Bloedjes, G. C. M. (2012). Cognitieve gedragstherapie: Behandelprotocol depressie: Therapeutenboek. Amsterdam: Boom. 
Bouman, T. K., \& Luteijn, F. (1986). Relations between the pleasant events schedule, depression, and other aspects of psychopathology. Journal of Abnormal Psychology, 95(4), 373-377.

Brouwer, M. E., Williams, A. D., van Grinsven, S. E., Cuijpers, P., Lambregtse-van den Berg, M. P., Burger, H. \& Bockting, C. L. H. (2018). Offspring outcomes after prenatal interventions for common mental disorders: A meta-analysis. BMC Medicine, 16, 208. > https://doi.org/10.1186/s12916-018-1192-6.

Carson, R. C., Hollon, S. D., \& Shelton, R. C. (2010). Depressive realism and clinical depression. Behaviour Research and Therapy, 48, 257-265.

Churchill, R., Hunot, V., Corney, R., Knapp, M., McGuire, H., \& Tylee, A. (2001). A systematic review of controlled trials of the effectiveness and cost-effectiveness of brief psychological treatments for depression. Health Technology and Assessment, 5, 1-173.

Cuijpers, P., \& Dekker, J. (2005). Psychological treatment of depression; a systematic review of meta-analyses. Nederlands Tijdschrift voor Geneeskunde, 149, 1892-1897.

Cuijpers, P., Andersson, G., Donker, T., \& van Straten, A. (2011). Psychological treatment of depression: Results of a series of meta-analyses. Nordic Journal of Psychiatry, 65(6), 354-364.

Cuijpers, P., Berking, M., Andersson, G., Quigley, L., Kleiboer, A., \& Dobson, K. S. (2013a). A meta-analysis of cognitive behavioural therapy for adult depression, alone and in comparison with other treatments. Canadian Journal of Psychiatry, 58(7), 376-385.

Cuijpers, P., Hollon, S. D., van Straten, A., Bockting, C., Berking, M., \& Andersson, G. (2013b). Does cognitive behaviour therapy have an enduring effect that is superior to keeping patients on continuation pharmacotherapy? A meta-analysis. BMJ Open, 3, e002542.

Cuijpers, P., Karyotaki, E., Weitz, E., Andersson, G., Hollon, S. D., \& van Straten, A. (2014). The effects of psychotherapies for major depression in adults on remission, recovery and improvement: A meta-analysis. Journal of Affective Disorders, 159, 118-126.

Cuijpers, P., Donker, T., Weissman, M. M., Ravitz, P., \& Cristea, I. A. (2016). Interpersonal psychotherapy for mental health problems: A comprehensive meta-analysis. American Journal of Psychiatry, 173, 680-687.

Cuijpers, P., van Straten, A., Andersson, G., \& van Oppen, P. (2008). Psychotherapy for depression in adults: A meta-analysis of comparative outcome studies. Journal of Consulting and Clinical Psychology, 76(6), 909-922.

Cuijpers, P., van Straten, A., \& Warmerdam, L. (2007). Behavioral activation treatment of depression: A metaanalysis. Clinical Psychology Review, 27, 318-326.

Cuijpers, P., van Straten, A., Schuurmans, J., van Oppen, P., Hollon, S. D., \& Andersson, G. (2010). Psychotherapy for chronic major depression and dysthymia: A meta-analysis. Clinical Psychology Review, 30(1), 51-62.

Cuijpers, P., van Straten, A., \& Smit, F. (2006). Psychological treatment of late-life depression: A meta-analyse of randomized-controlled trials. International Journal of Geriatric Psychiatry, 12, 1139-1149.

de Graaf, R., ten Have, M., \& van Dorsselaer, C. (2010). De psychische gezondheid van de Nederlandse bevolking NEMESIS-2: Opzet en eerste resultaten. Utrecht: Trimbos-instituut.

de Graaf, R., ten Have, M., van Gool, C., \& van Dorsselaer, C. (2012). Prevalentie van psychische aandoeningen en trends van 1996 tot 2009; resultaten van NEMESIS-2. Tijdschrift voor Psychiatrie, 1, 27-38.

de Graaf, L. E., Roelofs, J., \& Huibers, M. J. H. (2009). Measuring dysfunctional attitudes in the general population: The DAS-A revised. Cognitive Therapy and Research, 33, 345-355.

de Maat, S., Dekker, J., Schoevers, R., van Aalst, G., Gijsbers-van Wijk, C., Hendriksen, M., et al. (2008). Short psychodynamic supportive psychotherapy, antidepressants, and their combination in the treatment of major depression: A mega-analysis based on three randomized clinical trials. Depression and Anxiety, 25, 565-574.

Dimidjian, S., Hollon, S. D., Dobson, K. S., Schmaling, K. B., Kohlenberg, R. J., Addis, M. E., et al. (2006). Randomized trial of behavioral activation, cognitive therapy, and antidepressant medication in the acute treatment of adults with major depression. Journal of Consulting and Clinical Psychology, 74(4), 658-670.

Douma, M. (1991). The measurement of trait depression. Construction of Dutch dysfunctional attitude scale ( $A$ version) of Arlene Weissman. Meerssen: St. Lois Marie Jamin.

Driessen, E., Cuijpers, P., de Maat, S. C., Abbass, A. A., de Jonghe, F., \& Dekker, J. J. (2010). The efficacy of shortterm psychodynamic psychotherapy for depression: A meta-analysis. Clinical Psychology Review, 30(1), 25-36.

Driessen, E., Hollon, S. D., Bockting, C. L. H., Cuijpers, P., \& Turner, E. H. (2015). Does publication bias inflate the apparent efficacy of psychological treatment for major depressive disorder? A systematic review and metaanalysis of US national institutes of health-funded trials. PLOS ONE, 10(9), e0137864. 
Elgersma, H. J., de Jong, P. J., van Rijsbergen, G. D., Kok, G. D., Burger, H., van der Does, W., et al. (2015). Cognitive reactivity, self-depressed associations, and the recurrence of depression. Journal of Affective Disorders, 183, 300-309.

Elkin, I., Shea, M. T., Watkins, J. T., \& Imber, S. D. (1989). National institute of mental health treatment of depression collaborative research program: General effectiveness of treatments. Archives of General Psychiatry, 46(11), 971-982.

Ellis, A. (1962). Reason and emotion in psychotherapy. Secaurus: Lyle Stuart.

Gloaguen, V., Cottraux, J., Cucherat, M., \& Blackburn, I. (1998). A meta-analysis of the effects of cognitive therapy in depressed patients. Journal of Affective Disorders, 49(1), 59-72.

Hollon, S. D., \& Ponniah, K. (2010). A review of empirically supported psychological therapies for mood disorders in adults. Depression and Anxiety, 27(10), 891-932.

Hollon, S. D., DeRubeis, R. J., Fawcett, J., Amsterdam, J. D., Shelton, R. C., Zajecka, J., et al. (2014). Effect of cognitive therapy with antidepressant medications vs antidepressants alone on the rate of recovery in major depressive disorder: A randomized clinical trial. JAMA Psychiatry, 71(10), 1157-1164.

Hollon, S. D., DeRubeis, R. J., Shelton, R. C., Amsterdam, J. D., Salomon, R. M., O'Reardon, J. P., et al. (2005). Prevention of relapse following cognitive therapy vs medications in moderate to severe depression. Archives of General Psychiatry, 62(4), 417-422.

Jakobsen, J. C., Hansen, J. L., Simonsen, S., Simonsen, E., \& Gluud, C. (2012). Effects of cognitive therapy versus interpersonal psychotherapy in patients with major depressive disorder: A systematic review of randomized clinical trials with meta-analyses and trial sequential analyses. Psychological Medicine, 42, 1343-1357.

Huibers, M. J. H., Cohen, Z. D., Lemmens, L. H. J. M., Arntz, A., Peeters, F. P. M. L., Cuijpers, P., et al. (2015). Predicting optimal outcomes in cognitive therapy or interpersonal psychotherapy for depressed individuals using the personalized advantage index approach. PLOS ONE, 10(11), e0140771.

Karyotaki, E., Riper, H., Twisk, J., Hoogendoorn, A., Kleiboer, A., Mira, A., et al. (2017). Efficacy of self-guided internet-based cognitive behavioral therapy in the treatment of depressive symptoms: A meta-analysis of individual participant data. JAMA Psychiatry, 74(4), 351-359.

Kemmeren, L. L., van Schaik, D. J. F., Riper, H., Kleiboer, A. M., Bosmans, J. E., \& Smit, J. H. (2016). Effectiveness of blended depression treatment for adults in specialised mental healthcare: Study protocol for a randomised controlled trial. BMC Psychiatry, 16, 113.

Kenter, R., van de Ven, P. M., Cuijpers, P., Koole, G., Niamat, S., Gerrits, R. S., et al. (2015). Costs and effects of internet cognitive behavioral treatment blended with face-to-face treatment: Results from a naturalistic study. Internet Interventions, 2(1), 77-83.

Kooistra, L. C., Wiersma, J. E., Ruwaard, J., van Oppen, P., Smit, F., Lokkerbol, J., \& Riper, H. (2014). Blended vs. face-to-face cognitive behavioural treatment for major depression in specialized mental health care: Study protocol of a randomized controlled cost-effectiveness trial. BMC Psychiatry, 14, 290.

Lange, A. (1990). Strategieën in directieve therapie. Deventer: Van Loghum Slaterus.

Lemmens, L. H. J. M., Arntz, A., Peeters, F. P. M. L., Hollon, S. D., Roefs, A., \& Huibers, M. J. H. (2015). Clinical effectiveness of cognitive therapy vs. interpersonal psychotherapy for depression: Results of a randomized controlled trial. Psychological Medicine, 45, 2095-2110.

Lemmens, L. H. J. M., Galindo-Garre, F., Arntz, A., Peeters, F., Hollon, S. D., DeRubeis, R. J., et al. (2017). Exploring mechanisms of change in cognitive therapy and interpersonal psychotherapy for adult depression. Behaviour Research and Therapy, 94, 81-92.

Lemmens, L. H. J. M., van Bronswijk, S., Peeters, F., Arntz, A., Hollon, S. D., \& Huibers, M. J. H. (2018). Long-term outcomes of acute treatment with cognitive therapy vs. interpersonal psychotherapy for adult depression: Follow-up of a randomized controlled trial. Psychological Medicine, 24, 1-9.

Lewinsohn, P. M., Munoz, R. F., Youngren, M. A., \& Zeiss, A. M. (1986). Control your depression (2nd ed.). Englewood Cliffs: Prentice-Hall.

Luty, S. E., Carter, J. D., McKenzie, J. M., Rae, A. M., Frampton, C. M. A., Mulder, R. T., et al. (2007). Randomised controlled trial of interpersonal psychotherapy and cognitive-behavioural therapy for depression. British Journal of Psychiatry, 190, 496-502.

MacPhillamy, D. J., \& Lewinsohn, P. M. (1982). The pleasant events schedule: Studies on reliability, validity, and scale intercorrelation. Journal of Consulting and Clinical Psychology, 50, 363-380.

Moore, M. T., \& Fresco, D. M. (2012). Depressive realism: A meta-analytic review. Clinical Psychology Review, 32, 496-509. 
Mulder, R., Boden, J., Carter, J., Luty, S., \& Joyce, P. (2017). Ten month outcome of cognitive behavioural therapy $v$. interpersonal psychotherapy in patients with major depression: A randomised trial of acute and maintenance psychotherapy. Psychological Medicine, 47(14), 2540-2547.

Raes, F., Hermans, D., van den Broeck, K., \& Eelen, P. (2005). Kort Instrumenteel: De Nederlandstalige versie van de Dysfunctional Attitude Scale-vorm A (DAS-A-NL). Gedragstherapie, 38, 285-294.

Richards, D. A., Ekers, D., McMillan, D., Taylor, R. S., Byford, S., Warren, F. C., et al. (2016). Cost and Outcome of Behavioural Activation versus Cognitive Behavioural Therapy for Depression (COBRA): A randomised, controlled, non-inferiority trial. The Lancet, 388(10047), 871-880.

Satyanarayana, S., Enns, M. W., Cox, B. J., \& Sareen, J. (2009). Prevalence and correlates of chronic depression in the canadian community health survey: Mental health and well-being. Canadian Journal of Psychiatry, 54(6), 389-398.

Segal, Z. V., Kennedy, S., Gemar, M., Hood, K., Pedersen, R., \& Buis, T. (2006). Cognitive reactivity to sad mood provocation and the prediction of depressive relapse. Archives of General Psychiatry, 63, 749-755.

Spek, V., Cuijpers, P., Nyklicek, I., Riper, H., Keyzer, J., \& Pop, V. (2007). Internet-based cognitive behaviour therapy for symptoms of depression and anxiety: A meta-analysis. Psychological Medicine, 37(3), 319-328.

Spijker, J., Bockting, C. L. H., Meeuwissen, J. A. C., van Vliet, I. M., Emmelkamp, P. M. G., Hermens, M. L. M., et al. (2013). Multidisciplinaire Richtlijn Depressie (Derde revisie): Richtlijn voor de diagnostiek, behandeling en begeleiding van volwassen patiënten met een depressieve stoornis. Utrecht: Trimbos-instituut.

Svartberg, M., \& Stiles, T. C. (1991). Comparative effects of short-term psychodynamic psychotherapy: A metaanalysis. Journal of Consulting and Clinical Psychology, 59, 704-714.

Turner, E. H., Matthews, A. M., Linardatos, E., Tell, R. A., \& Rosenthal, R. (2008). Selective publication of antidepressant trials and its influence on apparent efficacy. New England Journal of Medicine, 358, 252-260.

van Driessen, E.,, H. L., Don, F. J., Peen, J., Kool, S., Westra, D., et al. (2013). The efficacy of cognitive-behavioral therapy and psychodynamic therapy in the outpatient treatment of major depression: A randomized clinical trial. American Journal of Psychiatry, 170(9), 1041-1050.

van Rijsbergen, G. D., Bockting, C. L., Burger, H., Spinhoven, P., Koeter, M. W., Ruhé, H. G., et al. (2013). Mood reactivity rather than cognitive reactivity is predictive of depressive relapse: A randomized study with 5.5year follow-up. Journal of Consulting and Clinical Psychology, 81(3), 508-517.

van Rijsbergen, G. D., Hollon, S. D., Elgersma, H. J., Kok, G. D., Dekker, J., Schene, A. H., et al. (2015). Understanding emotion and emotional scarring in recurrent depression. Comprehensive Psychiatry, 59, 54-61.

Vittengl, J. R., Clark, L. A., Dunn, T. W., \& Jarrett, R. B. (2007). Reducing relapse and recurrence in unipolar depression: A comparative meta-analysis of cognitive-behavioral therapy's effects. Journal of Consulting and Clinical Psychology, 75(3), 457-488.

Weissman, A. N., \& Beck, A. T. (1978). Development and validation of the dysfunctional attitude scale; paper presented at the annual meeting of the Association for the Advancement of Behavior Therapy.

Weisz, J. R., McCarty, C. A., \& Valeri, S. M. (2006). Effects of psychotherapy for depression in children and adolescents: A meta-analysis. Psychological Bulletin, 132(1), 132-149.

Wiersma, J. E., Hovens, J. G. F. M., van Oppen, P., Giltay, E. J., van Schaik, D. J. F., \& Beekman, A. T. F. (2009). The importance of childhood trauma and childhood life events for chronicity of depression. Journal of Clinical Psychiatry, 70, 983-989.

Wiersma, J. E., van Schaik, A., \& van Oppen, P. (2015). Cognitive Behavioral Analysis System of Psychotherapy (CBASP) voor de behandeling van chronische depressie. In M. Pijnenborg \& W. Scholten (Red.), Protocollen voor de GGZ. Houten: Bohn Stafleu van Loghum.

Zhou, X., Hetrick, S. E., Cuijpers, P., Qin, B., Barth, J., Whittington, C. J., et al. (2015). Comparative efficacy and acceptability of psychotherapies for depression in children and adolescents: A systematic review and network meta-analysis. World Psychiatry, 14(2), 207-222. 
